\title{
Refined Radiocarbon Chronologies for Northern Iroquoian Site Sequences: Implications for Coalescence, Conflict, and the Reception of European Goods
}

\author{
Jennifer Birch (D), Sturt W. Manning, Samantha Sanft, and Megan Anne Conger
}

\begin{abstract}
This article presents results to date of the Dating Iroquoia project. Our objective is to develop high-precision radiocarbon chronologies for northeastern North American archaeology. Here, we employ Bayesian chronological modeling of 184 AMS radiocarbon dates derived from 42 Northern Iroquoian village sites in five regional sequences in order to construct new date estimates. The resulting revised chronology demands a rethinking of key assumptions about cultural process in the region regarding the directionality and timing of processes of coalescence and conflict and the introduction of European trade goods. The results suggest that internal conflict may have preceded confederacy formation among the Haudenosaunee but not the Wendat, as has been previously assumed. External conflict, previously thought to have begun in the early seventeenth century, began more than a century earlier. New data also indicate that the timing and distribution of European materials were more variable between communities than acknowledged by the logic underlying traditional trade-good chronologies. This enhanced chronological resolution permits the development and application of archaeological theories that center the lived experiences and relational histories of Iroquoian communities, as opposed to the generalized thinking that has dominated past explanatory frameworks.
\end{abstract}

Keywords: radiocarbon dating, Bayesian chronological modeling, Northern Iroquoian archaeology, settlement patterns, conflict, European trade goods

Cet article présente les résultats obtenus jusqu'à présent dans le cadre du projet intitulé «Dating Iroquoia» (Datation de l'Iroquoisie). Notre objectif consiste à mettre au point des chronologies radiocarbone de haute précision dans le cadre de l'archéologie de la partie nord-est de l'Amérique du Nord. À cette fin, nous employons une modélisation chronologique Bayésienne de datations radiocarbone par SMA 184, en provenance de 42 sites villageois Iroquoiens du Nord, selon cinq séquences régionales, dans le but d'établir de nouvelles estimations de dates. Cette nouvelle chronologie incite à revoir les principales hypothèses liées au processus culturel dans la région concernant l'orientation et le calendrier des mécanismes de coalescence et de conflit, ainsi que l'introduction d'échanges commerciaux avec les Européens. Les résultats laissent à penser que les conflits internes peuvent avoir précédé l'établissement de la confédération avec les Haudenosaunee, mais non pas avec les Wendat, comme on a jusqu'à présent pensé. Les conflits externes, censés avoir démarré au début du dix-septième siècle, ont commencé plus d'un siècle auparavant. De nouvelles données indiquent également que le calendrier et la distribution des matières européennes ont davantage varié entre les communautés qu'il n'est reconnu selon la logique sous-tendant les chronologies traditionnelles d'échanges commerciaux. Cette résolution chronologique améliorée permet de développer et d'appliquer des théories archéologiques mettant l'accent sur les expériences vécues et les antécédents relationnels des communautés iroquoiennes, contrairement à la réflexion généralisée qui a dominé les anciens cadres explicatifs.

Mots-clés: datations radiocarbone, modélisation chronologique Bayésienne, conflit, d'échanges commerciaux avec les Européens

hronologies fundamentally underpin all other aspects of archaeological thought. The time frames we employ structure not only the broad brushstrokes of cultural process at the regional scale but also the questions we are willing to ask of our data and the answers we are

Jennifer Birch (corresponding author; jabirch@uga.edu) and Megan Anne Conger (megan.conger25@uga.edu)

- Department of Anthropology, University of Georgia, 250 Baldwin Hall, 355 S. Jackson St., Athens, 30602-1619, GA, USA Sturt W. Manning — Cornell Tree Ring Laboratory, Department of Classics, 120 Goldwin Smith Hall, and Cornell Institute of Archaeology and Material Studies, Cornell University, Ithaca, NY 14853, USA (sm456@ cornell.edu)

Samantha Sanft $\square$ Department of Anthropology, 261 McGraw Hall, and Cornell Institute of Archaeology and Material Studies, Cornell University, Ithaca, New York 14853, USA (sms625@ cornell.edu)

American Antiquity 86(1), 2021, pp. 61-89

Copyright (C The Author(s), 2020. Published by Cambridge University Press on behalf of Society for American Archaeology. This is an Open Access article, distributed under the terms of the Creative Commons Attribution licence (http://creativecommons.org/licenses/by/4.0/), which permits unrestricted re-use, distribution, and reproduction in any medium, provided the original work is properly cited. doi:10.1017/aaq.2020.73 


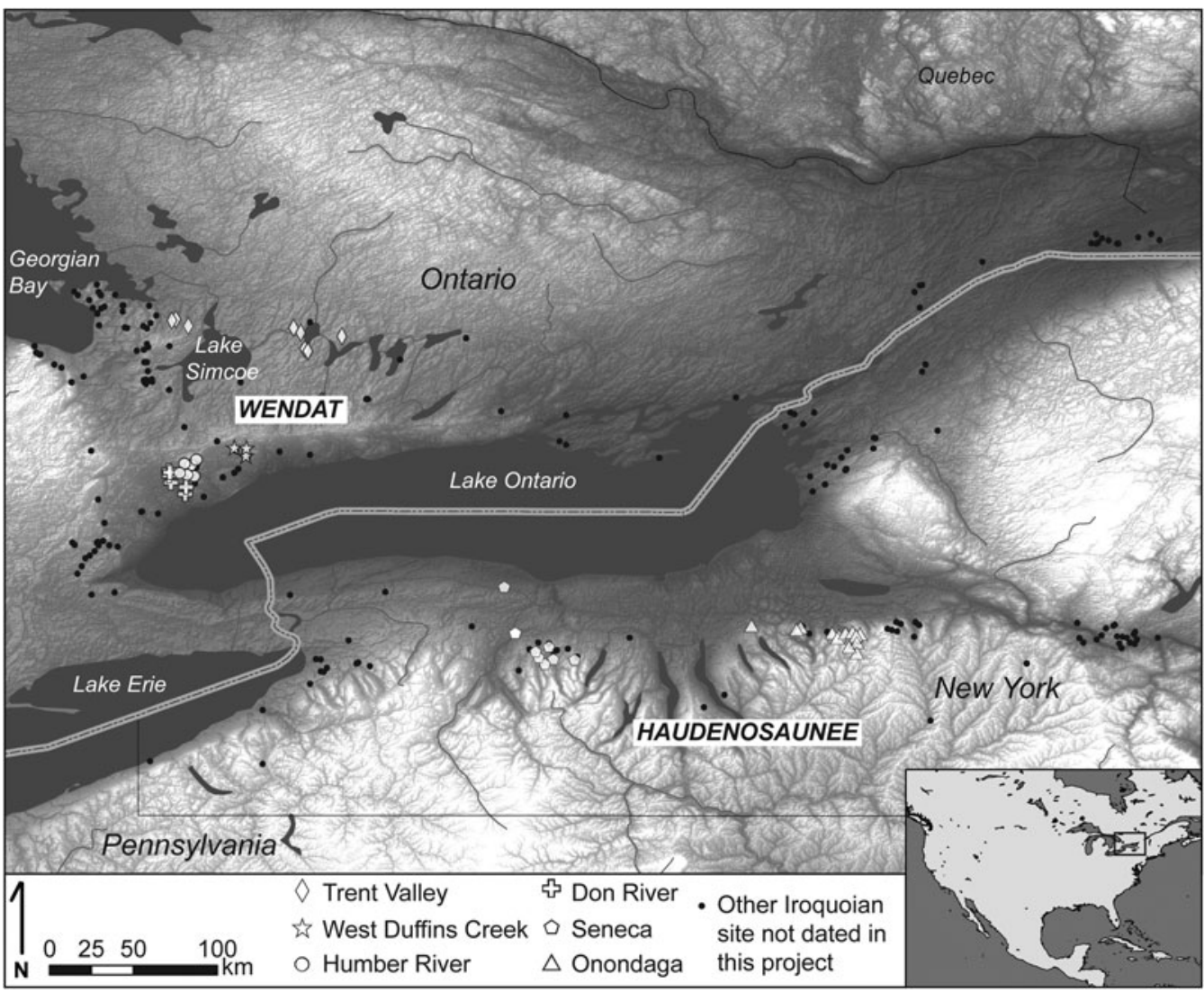

Figure 1. Map of the study region with dated and selected undated sites indicated (undated site locations are intended to be representative as opposed to definitive; dataset follows Hart et al. 2019). Basemap: United States Geological Survey 2017. Waterways and inset basemap: Natural Earth 2019.

willing to accept. The use of Bayesian modeling for the interpretation of radiocarbon dates and the construction of refined archaeological chronologies has had a tremendous impact on the discipline (Bayliss 2009, 2015; Bayliss and Bronk Ramsey 2004; Bronk Ramsey 2009a), resulting in the rethinking of long-held ideas about the historical development of societies in multiple world regions (e.g., Bronk Ramsey et al. 2010; Higham and Higham 2009; Manning et al. 2006, 2018; Needham et al. 1998; Whittle 2018; Whittle et al. 2011). The ability to refine and revise archaeological chronologies forces a critical recontextualization of both regional cultural sequences and the conceptual frameworks we use to explain them.

This article describes the initial results of the Dating Iroquoia project. Our objective has been to construct high-precision radiocarbon chronologies for selected Northern Iroquoian site relocation sequences in eastern North America (Figure 1). Results suggest that in some cases, previous age estimates were in error by some 75-100 years (see also Manning et al. 2018). Given the largely single-component nature of site occupations, estimated to span some $0-40$ years, such shifts can be seismic. Although our results should be viewed as a first step toward a refined, radiocarbon-derived chronology for northeastern archaeology, these findings nevertheless require a rethinking of long-held notions about cultural process in Northern Iroquoia. This includes current understandings of the timing and nature of coalescence and conflict as well as the spread of European goods and influences from the fifteenth to seventeenth century. Our discussion of these data and findings stress the importance of using derived insights from enhanced chronological resolution 
for archaeological interpretation. In particular, we highlight that refined chronologies permit the writing of a new kind of archaeological history that extends beyond generalized cultural processes and focuses on the relational histories of communities, peoples, and places. In doing so, we forefront the agency of Indigenous peoples and the positionality of specific community groups during processes of coalescence, conflict, and early encounters with European objects and persons.

\section{Iroquoian Archaeology}

Northern Iroquoian societies inhabited what is now southern Ontario, southwest Québec, upper New York State, and the Susquehanna Valley of Pennsylvania and New York. These populations shared cultural traits, including settlements of bark-covered longhouses sometimes surrounded by palisades; subsistence based on maize horticulture, hunting, fishing, and gathering; and a sociopolitical structure organized around matrilineal descent, clan membership, and decision making based on councils and consensus building (Engelbrecht 2003; Trigger 1976). In the sixteenth and seventeenth centuries, certain of these groups, notably the Wendat (Huron) and Haudenosaunee (Iroquois) were organized into regional confederacies that included nations of allied villages and a confederacy council (Fenton 1998; Trigger 1976), although the specific structure and social networks comprising each were variable (Birch and Hart 2018).

Seventeenth-century European explorers and missionaries left a detailed ethnohistoric record of Iroquoian lifeways. As a result, a great deal of Iroquoian archaeology has involved variants of the direct historical approach. Archaeological remains that include Iroquoian cultural traits or stages of their development are thought to represent ancestral Iroquoian-speaking peoples (Snow 1994; Warrick 2000:417). However, the relationship between what has been interpreted as constituting early forms of longhouses, horticulture, and sociopolitical organization versus historically documented phenomena is less clear than such models assume (e.g., Hart 2011; Hart and Brumbach 2003; Pihl et al. 2008). Contemporary Indigenous peoples have been particularly critical of inferred relationships between material culture and ethnic identity (Gaudreau and Lesage 2016).

\section{Iroquoian Chronology and Cultural Process}

Chronological frameworks for Iroquoian archaeology have primarily been based on ceramic seriation (ca. AD 1000-1550; all dates in this article are AD) and European trade goods (ca. AD 1550 through to the historic period), together with small numbers of modern radiocarbon dates and larger numbers of legacy dates (Figure 2). Although archaeologists in Ontario have a basic understanding of long-term cultural process during the Woodland period, it has been recognized for some time that this framework is inadequate for addressing questions related to complex cultural behavior (Ferris and Spence 1995:83; Williamson 1999). It has started to become clear, however, that enhancing our chronological resolution does not serve to clarify existing chronological frameworks. Instead, it renders them obsolete - both in practice and in theory.

Focused effort on ceramic seriation in Iroquoian archaeology began in the mid-twentieth century with the definition of ceramic types and their chronological associations, working backward from documented interactions with Europeans in the early seventeenth century to what was interpreted as early manifestations of Iroquoian culture (Emerson 1954; MacNeish 1952; Wright 1966). Beginning in the 1970s, analytical approaches shifted to seriation based on ceramic attributes rather than types, but they maintained similar relative chronologies (e.g., Engelbrecht 1971; Ramsden 1977). The growth of settlement archaeology led to the construction of inferred site relocation sequences based on ceramic seriation that have been the basis for narratives of cultural development in both Ontario and New York State (e.g., Ramsden 1977; Sempowski and Saunders 2001; Tuck 1971).

From the mid-sixteenth century on, sites are more commonly dated based on the presence or absence of European metal and chronologically diagnostic glass-bead assemblages. It is generally accepted that European metal appears on Iroquoian sites as early as the mid-sixteenth century (Bradley 2005, 2007; Bradley and Childs 1991; Fitzgerald 1990; Loewen and Chapdelaine 


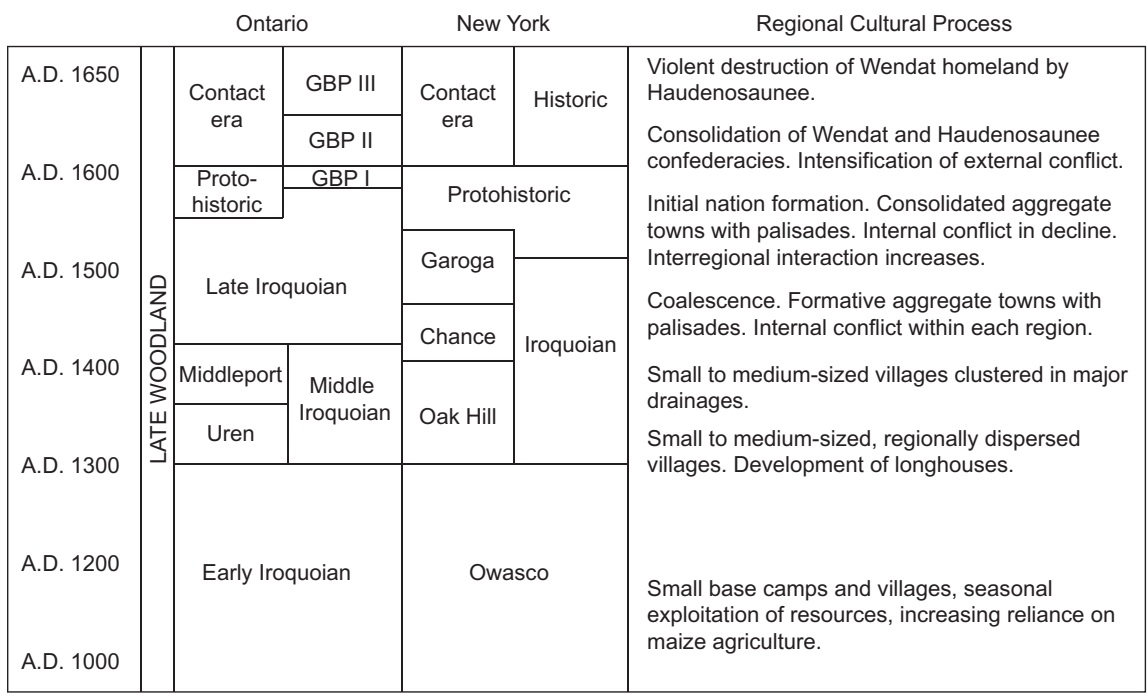

Figure 2. Traditional regional chronology (after Bradley 2005; Ellis and Ferris 1990; Engelbrecht 2003; Wright 1966).

2016; Wray and Schoff 1953). Small amounts of European iron and copper are assumed originally to have passed through Indigenous trade networks, and they were later followed by other goods acquired directly from Europeans, including glass beads, copper and brass kettles, and iron knives and axes. Trade good distributions have been used to construct timelines such as the glass-bead chronology (Kenyon and Fitzgerald 1986; Kenyon and Kenyon 1983; Rumrill 1991) and to chronologically order sites more generally based on frequencies and types of European goods (e.g., Birch and Williamson 2013; Loewen 2016). Contemporary perspectives on processes of cultural entanglement, Indigenous agency, and differential engagements between multiple Indigenous and European actors in the sixteenth and seventeenth centuries prompt critical reflection on the logic of both these frameworks (Jordan 2009, 2013; Loewen and Chapdelaine 2016).

Generally, radiocarbon dating has only been utilized on pre-1550 Iroquoian sites, with tradegood chronologies the preferred dating method on "protohistoric" and "historic" era sites. In the past, radiocarbon dating in Late Woodland Iroquoian archaeology was often employed in order to confirm the assignment of sites to certain cultural phases (e.g., Uren, Chance, etc.; see
Figure 2), with dates that did not "fit" the dominant paradigm being dismissed as inaccurate (e.g., Ellis and Ferris 1990). An oft-cited problem in Iroquoian archaeology over the last several decades is the lack of chronological resolution possible from radiocarbon dates. This stems from the combination of short durations of site occupation and multiple possible intercepts in the calibration curve between 1300 and 1650 (e.g., Chapdelaine 2016; Ramsden 2014; Rossen 2015), and it applies especially between 1480 and 1620 , where a major plateau and reversal in the calibration curve renders radiocarbon dates ambiguous in the absence of chronological modeling (Figure 3). More precise AMS dating, together with chronological modeling, has demonstrated that we now have the ability to begin to overcome those concerns (Manning and Hart 2019; Manning et al. 2018, 2019, 2020).

\section{Coalescence, Conflict, and Interactions with Europeans}

The cultural processes at the center of this investigation are (1) the timing and process of coalescence and conflict, and (2) the entry and distribution of European-manufactured material culture in the region. Both phenomena have been placed in the mid-1400s and mid-1500s, respectively. 


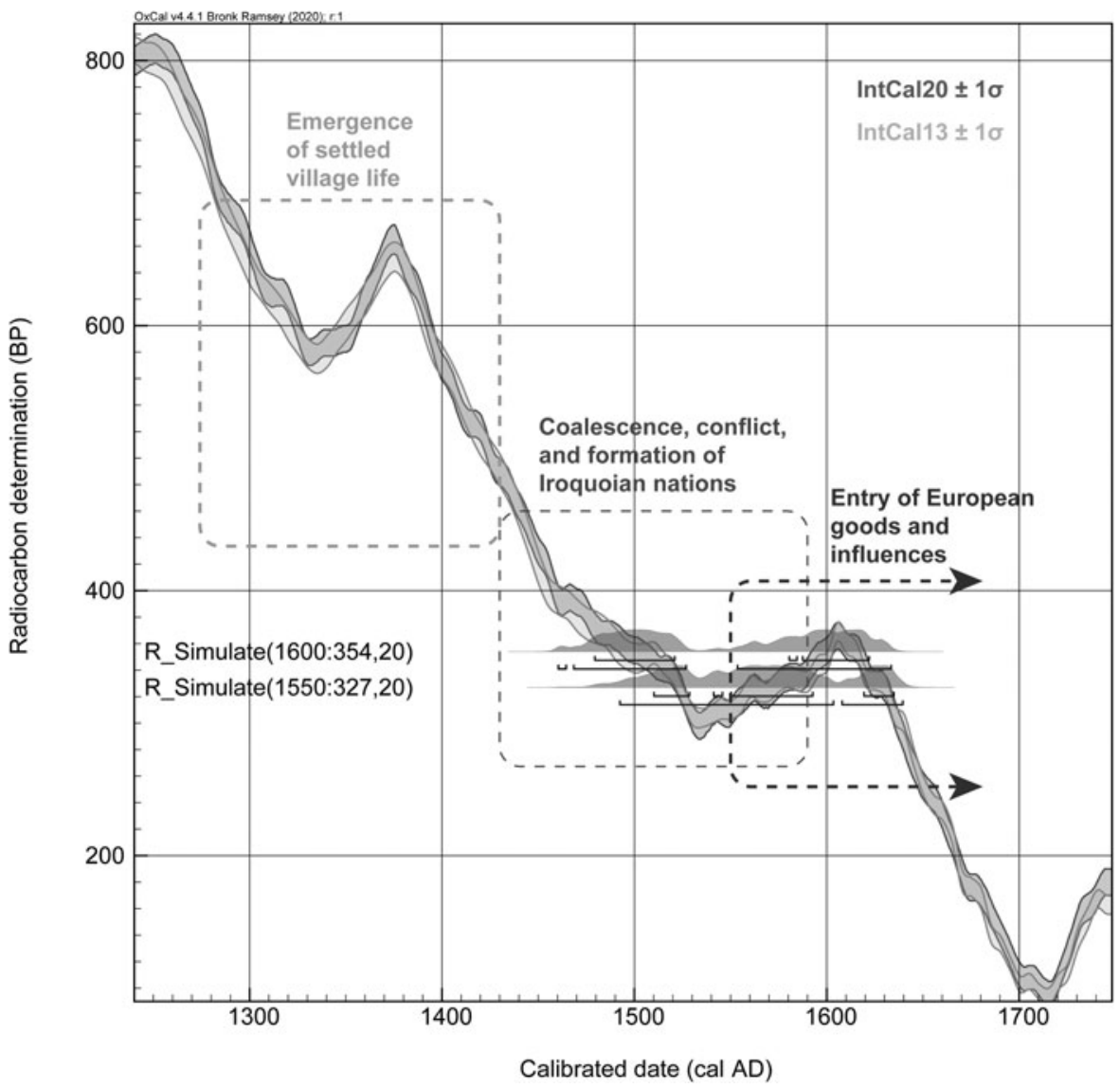

Figure 3. Calibration curve with area of sixteenth-century plateau/wiggle and related cultural phenomena indicated. Simulated dates illustrate the multiple intercepts, long date intervals, and therefore the challenges associated with radiocarbon dating in this period. The new IntCal20 calibration curve (dark gray; Reimer et al. 2020) is shown as well as the previous IntCal13 calibration curve (light gray; Reimer et al. 2013).

At the end of the Late Woodland period in both Ontario and New York State, people came together into heavily palisaded and defensively situated, aggregated village settlements in the context of heightened regional conflict. Some sites also include clear sequences of village expansion where palisades were extended to incorporate newcomers (Birch 2012; Finlayson 1985; Finlayson et al. 1987; Ramsden 2016; Sempowski and Saunders 2001; Snow 1995; Tuck 1971). Palisaded village sites in both regions are often, although not always, found to contain human remains in nonburial contextssuch as midden deposits-with perimortem trauma interpreted as evidence of the torture and killing of captives (Williamson 2007).
It has been assumed that coalescence and conflict in Ontario were occurring as early as approximately 1450 (Birch 2010, 2012; Birch and Williamson 2013). The early onset of conflict, together with analysis of human skeletal remains (Dupras and Pratte 1998; Williamson 2007), led to the inference that conflict in Ontario was primarily occurring between local groups and that it declined in intensity during the very early 1500s (Birch 2010, 2012). In New York State, however, palisaded settlements were thought to appear somewhat later, in the very late 1400 s to early 1500s (Engelbrecht 2003; Snow 1994). This pattern was also understood as having developed as the result of intrasocietal conflict, based in part on ethnographic accounts 
of the founding of the Haudenosaunee confederacy in order to quell intrasocietal violence (e.g., Fenton 1998). It has been assumed that conflict between the Haudenosaunee and Wendat only escalated in the very late 1500 s to early 1600 s (Trigger 1976). Multiple ethnohistoric accounts also describe external warfare between various Iroquoian and non-Iroquoian nations and tribal groups. Ultimately, the intensification of attacks by the Haudenosaunee eventually led to dispersal of the Wendat and other Iroquoian nations in the early 1650 s.

After limited Norse presence approximately AD 1000, direct interaction between Indigenous peoples and Europeans was first recorded by Jacques Cartier in the St. Lawrence River valley in 1535 (Biggar 1929-1936), although Basque fishers and whalers had a presence on the coast some decades earlier (Turgeon 2001). Until the early seventeenth century, when Europeans established a sustained presence in the Northeast, it is assumed that European goods on Indigenous sites in Ontario and New York originated mostly from direct exchanges between Basque or French mariners and Indigenous peoples along the north Atlantic Coast and in the Saint Lawrence Valley. It was assumed that these items were then traded inland through existing Indigenous networks of exchange and affiliation (e.g., Loewen and Chapdelaine 2016). Although archival research has characterized "diagnostic" assemblages of European goods being produced and exported at specific times from specific places (e.g., Bradley 1980; Fitzgerald 1995; Fitzgerald et al. 1993; Turgeon 2001), relative chronologies of European goods-such as glass beads-have largely been constructed using the direct historical method, working backward along site sequences anchored by sites supposedly identified in the ethnohistoric record (e.g., Kenyon and Kenyon 1983; Wray and Schoff 1953). Even though the impact of Indigenous perceptions of, and preferences among, these newly available goods has been explored to a certain extent (Anselmi 2004), such goods are still widely used as temporal markers (e.g., Hawkins et al. 2016; Walder 2018), following the fundamental assumption that once they became available, they would be present in all communities in identifiable quantities. While variability among communities in terms of trade-good assemblages has been acknowledged for some time (Ramsden 1978), it was not until recently that this variability was explicitly demonstrated through independent dating (Manning and Hart 2019; Manning et al. 2018, 2019).

Current narratives about these processes mainly fit into time frames based on tentative associations between sites and rough, approximately 20-50-year phases, making it difficult to associate processes in one sequence or region with another. Figure 2 illustrates the time frames previously assigned to sites in this study. Traditional chronologies do not permit the teasing out of associations between sites and sequences with enough precision to engage meaningfully in relational approaches to archaeological histories (e.g., Kosiba 2019). For example, what does coalescence on the north shore of Lake Ontario have to do with similar processes taking place in the Finger Lakes Region of New York State? How does evidence for the intensification of conflict in one area relate to the co-occurrence or absence of evidence for conflict in others? Does the entry of European goods into communities actually occur at the same time across the region? Alternatively, is there variability between subregions, as recent work on the West Duffins Creek sequence seems to demonstrate (Manning et al. 2018)? What, if any, influence did long-distance trade and the onset of early European interaction have on communities, and how did those events impact processes of coalescence and conflict? These questions are historical in nature-they focus on a fundamental interest in diversity and specific, localized experience. To answer them, we require finer chronological resolution than relative means of dating currently offer.

\section{Village Relocation Sequences}

This study focuses on dating village sites that comprise subregional sequences of village relocations. Iroquoian villages were generally singlecomponent, and they were occupied for no more than 40 years. Multiple lines of evidence support this interpretation. Warrick (1988) provides a lengthy and compelling argument for estimating Iroquoian village duration using various methods. He argued that the average density of 
house wall posts was the most viable means of estimation (Warrick 1988, 2008:125). Counts of excavated posts in longhouse walls, combined with estimated rates of rotting and repair of multiple tree species available to Iroquoian builders, were employed to determine the average length of occupation for village sites in various periods of Iroquoian cultural development. He determined that sites were occupied for an average of 25-30 years in the fifteenth and sixteenth centuries.

Ethnohistoric accounts of Iroquoian village relocation are highly variable. In the writings of Champlain and Sagard, who visited Wendake during the 1610s and 1620s, village durations are reported variously as ranging from 10 to 40 years (Biggar 1929-1936; Wrong 1939 [1632]). In the 1630s and 1640s, Jesuits living among the Wendat reported village abandonment occurring after 8-12 years (Thwaites 1896-1901).

Typically, village duration is stated as a likely maximum duration of no greater than 40 years. There is furthermore a general view that the larger, later sites were typically occupied for much shorter intervals (Birch 2015; Birch and Williamson 2013; Warrick 1988). Consequently, most village durations in the sixteenth to seventeenth century were probably closer to 10-20 years, and only a few were occupied for more than 20 or, at most, $30-40$ years. When villages were relocated, they often moved nearby-usually only a few kilometers away-although longer migrations also took place. Explanations for village relocation have been functional or ecological as well as social and political (Jones and Wood 2012; Warrick 2008).

Numerous site relocation sequences have been constructed that represent hundreds of years of activity by contiguous groups (e.g., Birch and Williamson 2013; Bradley 2005; Niemczycki 1984; Ramsden 1977; Sempowski and Saunders 2001; Snow 1995; Tuck 1971). Although in most cases the general sequence of site occupations in each subregion is relatively well established, contemporaneity between sites across sequences has been inferred based on subregional ceramic chronologies and trade-good frequencies. This study is the first attempt to establish largely independent time frames for several known sequences.
For example, a refined chronology for the community relocation sequence representing the Draper, Spang, and Jean-Baptiste Lainé (Mantle) sites has demonstrated this potential and the implications for associated conceptual frameworks. These three sites are understood to be sequential iterations of the same village community (Birch and Williamson 2013). This village sequence was previously thought to date to roughly 1450-1530. However, 67 new radiocarbon dates modeled in keeping with current understandings have shown that it actually dates to approximately 1528-1616 (Manning et al. 2018)-75-100 years later than previous estimates. This independent, radiocarbonderived chronology is at odds with the longstanding ceramic and trade-good chronologies (Kenyon and Kenyon 1983; Ramsden 1990). If this sequence was so misdated, what then of others in the region?

This investigation focuses specifically on three sequences of village sites ancestral to the Huron-Wendat Nation located in the Humber, Don, and Trent River systems in southern Ontario and two associated with the Seneca and Onondaga Nations of the Haudenosaunee in New York State (Figure 1; see Supplemental Table 1 for detailed site descriptions). These site sequences were chosen because of their centrality in explanatory constructs related to the archaeological histories of Iroquoian peoples in each region and the availability of sample material.

\section{Methods}

\section{Sample Selection}

All samples selected for radiocarbon dating were acquired from extant collections derived from cultural resource management, research, or avocational field projects. For some villages, only site-level provenience data were available. For others, samples were acquired from intact features such as pits, posts, and midden deposits (Table 1; Supplemental Table 1). When sites included multiple occupational phases, samples were taken from longhouses or other features associated with each phase and used to inform the modeling. In keeping with the wishes of 
Table 1. New Radiocarbon Dates Produced by This Project.

\begin{tabular}{|c|c|c|c|c|c|c|c|c|c|}
\hline Site & Lab Number & Material & $\begin{array}{c}\text { CRA } \\
{ }^{14} \mathrm{C} \\
\text { Age BP }\end{array}$ & \pm & $\delta^{13} \mathrm{C}$ & ${ }^{15} \mathrm{~N}$ & $\mathrm{C}: \mathrm{N}$ & $\begin{array}{c}\text { Calibrated } \\
\text { Date Range } \\
95.4 \%\end{array}$ & $\begin{array}{c}\text { Calibrated } \\
\text { Date Range } \\
68.3 \%\end{array}$ \\
\hline \multicolumn{10}{|l|}{ SENECA } \\
\hline Farrell & GrM-14970 & unid. nut & 558 & 20 & -24.56 & & & $1323-1423$ & $1328-1414$ \\
\hline Farrell & UGAMS-34030 & maize & 588 & 22 & -9.46 & & & 1306-1409 & $1323-1400$ \\
\hline Farrell & GrM-14972 & unid. nut & 518 & 20 & -26.13 & & & $1401-1438$ & $1409-1426$ \\
\hline Footer & UGAMS-34031 & maize & 372 & 21 & -8.93 & & & $1454-1630$ & $1464-1617$ \\
\hline Footer & GrM-13830 & maize & 384 & 15 & -7.62 & & & $1452-1619$ & $1457-1607$ \\
\hline Footer & GrM-13832 & maize & 382 & 15 & -8.41 & & & $1452-1620$ & $1458-1610$ \\
\hline Footer & UGAMS-34032 & maize & 374 & 21 & -9.34 & & & $1453-1627$ & $1460-1616$ \\
\hline Belcher & UGAMS-34024 & maize & 347 & 21 & -9.96 & & & $1472-1635$ & $1490-1626$ \\
\hline Belcher & GrM-13829 & maize & 343 & 15 & -9.33 & & & $1478-1634$ & $1495-1628$ \\
\hline Belcher & UGAMS-39603 & bone collagen & 379 & 20 & -22.09 & 9.10 & 3.2 & $1451-1624$ & $1458-1615$ \\
\hline Richmond Mills & UGAMS-34033 & maize & 352 & 21 & -9.90 & & & $1460-1635$ & $1482-1623$ \\
\hline Richmond Mills & GrM-13756 & maize & 355 & 15 & -8.30 & & & $1472-1632$ & $1483-1620$ \\
\hline Richmond Mills & UGAMS-35645 & maize & 352 & 19 & -8.86 & & & $1468-1634$ & $1483-1623$ \\
\hline Richmond Mills & GrM-14985 & maize & 332 & 18 & -8.75 & & & $1490-1638$ & $1505-1633$ \\
\hline Richmond Mills & UGAMS-35646 & maize & 332 & 19 & -9.61 & & & $1490-1638$ & $1504-1634$ \\
\hline Richmond Mills & GrM-14986 & maize & 328 & 18 & -8.35 & & & $1494-1638$ & $1509-1634$ \\
\hline Richmond Mills & UGAMS-35647 & maize & 311 & 19 & -8.49 & & & $1500-1645$ & $1522-1639$ \\
\hline Richmond Mills & GrM-14987 & maize & 341 & 20 & -8.69 & & & $1478-1635$ & $1495-1631$ \\
\hline Alhart & UGAMS-34021 & bean & 305 & 21 & -28.75 & & & $1504-1649$ & $1523-1641$ \\
\hline Alhart & UGAMS-34022 & bean & 316 & 21 & -26.66 & & & 1497-1644 & $1521-1637$ \\
\hline Alhart & UGAMS-34023 & maize & 291 & 21 & -9.34 & & & $1516-1656$ & $1524-1648$ \\
\hline Alhart & GrM-13828 & maize & 308 & 15 & -8.29 & & & $1515-1644$ & $1524-1639$ \\
\hline Tram & GrM-14973 & hickory nut & 351 & 20 & -24.54 & & & $1467-1635$ & $1485-1623$ \\
\hline Tram & UGAMS-39607 & unid. charcoal & 287 & 20 & -24.84 & & & $1520-1658$ & $1526-1650$ \\
\hline Cameron & UGAMS-34025 & maize & 338 & 21 & -9.85 & & & $1480-1636$ & 1499-1631 \\
\hline Cameron & UGAMS-34027 & maize & 344 & 21 & -8.54 & & & $1475-1635$ & $1491-1631$ \\
\hline Cameron & GrM-13759 & maize & 354 & 15 & -8.71 & & & $1473-1632$ & $1485-1621$ \\
\hline Cameron & UGAMS-34026 & maize & 372 & 21 & -8.89 & & & $1454-1630$ & $1464-1617$ \\
\hline Cameron & GrM-13760 & maize & 344 & 15 & -8.18 & & & $1479-1634$ & $1495-1626$ \\
\hline Factory Hollow & UGAMS-34028 & maize & 372 & 22 & -10.18 & & & $1453-1631$ & $1462-1617$ \\
\hline Factory Hollow & GrM-13827 & maize & 347 & 15 & -8.87 & & & $1478-1633$ & $1491-1625$ \\
\hline Factory Hollow & UGAMS-34029 & plum pit shell & 355 & 21 & -26.00 & & & $1463-1633$ & $1479-1623$ \\
\hline Factory Hollow & GrM-13757 & plum pit shell & 377 & 15 & -24.74 & & & $1455-1621$ & $1460-1612$ \\
\hline \multicolumn{10}{|l|}{ ONONDAGA } \\
\hline Kelso & GrM-14982 & maize & 543 & 20 & -8.73 & & & $1326-1428$ & $1400-1422$ \\
\hline Kelso & UGAMS-35644 & maize & 576 & 19 & -8.66 & & & $1317-1413$ & $1326-1404$ \\
\hline Kelso & GrM-14983 & maize & 624 & 25 & -8.21 & & & $1298-1397$ & $1302-1394$ \\
\hline Howlett Hill & UGAMS-35637 & maize & 506 & 19 & -7.94 & & & $1406-1440$ & $1414-1433$ \\
\hline Schoff & UGAMS-39598 & bone collagen & 434 & 25 & -26.97 & 4.00 & 3.3 & $1425-1486$ & $1436-1463$ \\
\hline Bloody Hill & UGAMS-35640 & maize & 362 & 19 & -8.14 & & & $1458-1631$ & $1475-1620$ \\
\hline Bloody Hill & GrM-14990 & maize & 373 & 20 & -8.70 & & & $1455-1625$ & $1460-1617$ \\
\hline Christopher & UGAMS-37379 & bone collagen & 338 & 20 & -22.79 & 6.01 & 3.4 & $1480-1636$ & $1500-1631$ \\
\hline Burke & UGAMS-35641 & maize & 359 & 19 & -9.09 & & & $1460-1631$ & $1478-1620$ \\
\hline Burke & GrM-14988 & maize & 363 & 18 & -8.57 & & & $1458-1631$ & $1474-1620$ \\
\hline Burke & GrM-14980 & bean & 360 & 18 & -24.45 & & & $1459-1631$ & $1477-1620$ \\
\hline Cemetery & UGAMS-35642 & bean & 316 & 19 & -27.18 & & & 1499-1644 & $1521-1637$ \\
\hline Cemetery & GrM-14991 & bean & 359 & 18 & -26.27 & & & $1460-1631$ & $1478-1620$ \\
\hline Cemetery & UGAMS-35643 & maize & 335 & 20 & -7.98 & & & $1485-1637$ & $1501-1633$ \\
\hline Barnes & UGAMS-39589 & bone collagen & 315 & 20 & -21.18 & 5.58 & 3.4 & 1499-1644 & $1521-1638$ \\
\hline $\mathrm{McNab}$ & UGAMS-37377 & bone collagen & 298 & 35 & -22.43 & 5.36 & 3.3 & $1487-1660$ & $1520-1647$ \\
\hline $\mathrm{McNab}$ & UGAMS-37378 & bone collagen & 290 & 20 & -22.83 & 4.98 & 3.3 & $1517-1657$ & $1525-1648$ \\
\hline Temperance House & UGAMS-39611 & bone collagen & 282 & 20 & -22.36 & 7.22 & 3.2 & $1520-1660$ & $1528-1650$ \\
\hline
\end{tabular}


Table 1. Continued.

\begin{tabular}{|c|c|c|c|c|c|c|c|c|c|}
\hline Site & Lab Number & Material & $\begin{array}{c}\text { CRA } \\
{ }^{14} \mathrm{C} \\
\text { Age BP }\end{array}$ & \pm & $\delta^{13} \mathrm{C}$ & ${ }^{15} \mathrm{~N}$ & C:N & $\begin{array}{c}\text { Calibrated } \\
\text { Date Range } \\
95.4 \%\end{array}$ & $\begin{array}{c}\text { Calibrated } \\
\text { Date Range } \\
68.3 \%\end{array}$ \\
\hline Temperance House & UGAMS-39612 & bone collagen & 304 & 20 & -23.33 & 6.33 & 3.2 & $1506-1649$ & $1524-1641$ \\
\hline Atwell & UGAMS-39586 & bone collagen & 312 & 20 & -22.08 & 6.38 & 3.4 & 1499-1645 & $1522-1638$ \\
\hline Atwell & UGAMS-39588 & bone collagen & 285 & 20 & -21.98 & 7.04 & 3.4 & $1520-1659$ & $1526-1650$ \\
\hline Chase & UGAMS-39592C & bone collagen & 300 & 25 & -22.09 & 7.77 & 3.4 & $1500-1655$ & $1522-1644$ \\
\hline Chase & UGAMS-39592E & bone collagen & 388 & 25 & -16.85 & & & $1445-1625$ & $1453-1615$ \\
\hline Chase & UGAMS-39593 & bone collagen & 372 & 20 & -23.78 & 5.15 & 3.4 & $1455-1627$ & $1464-1617$ \\
\hline Pompey Center & UGAMS-35648 & maize & 350 & 19 & -8.86 & & & $1470-1635$ & $1487-1624$ \\
\hline Pompey Center & UGAMS-39595 & maize & 300 & 20 & -9.73 & & & $1510-1650$ & $1524-1643$ \\
\hline Pompey Center & UGAMS-39596 & maize & 306 & 20 & -9.23 & & & $1506-1648$ & $1523-1640$ \\
\hline \multicolumn{10}{|l|}{ HUMBER } \\
\hline Black Creek & UGAMS-35635 & bone collagen & 351 & 21 & -22.27 & 6.126 & 3.3 & $1466-1635$ & $1484-1624$ \\
\hline Black Creek & UGAMS-35636 & bone collagen & 400 & 20 & -22.55 & 5.511 & 3.2 & $1444-1618$ & $1450-1483$ \\
\hline Parsons & UGAMS-33008 & maize & 324 & 21 & -9.24 & & & 1493-1640 & $1515-1635$ \\
\hline Parsons & GrM-14963 & maize & 334 & 20 & -8.90 & & & 1486-1637 & $1501-1633$ \\
\hline Parsons & UGAMS-33009 & maize & 342 & 21 & -9.81 & & & $1477-1636$ & $1494-1631$ \\
\hline Parsons & GrM-14962 & maize & 353 & 30 & -9.20 & & & $1459-1635$ & $1478-1626$ \\
\hline Seed-Barker & GrM-14965 & maize & 297 & 18 & -10.40 & & & $1516-1650$ & $1524-1644$ \\
\hline Seed-Barker & UGAMS-33003 & maize & 335 & 21 & -10.27 & & & $1484-1637$ & $1500-1633$ \\
\hline Seed-Barker & GrM-14966 & maize & 345 & 40 & -8.93 & & & $1460-1638$ & $1485-1631$ \\
\hline Seed-Barker & UGAMS-33004 & maize & 350 & 20 & -10.20 & & & $1470-1635$ & $1485-1624$ \\
\hline Seed-Barker & UGAMS-33004ha & humic acid & 357 & 21 & -10.00 & & & $1460-1633$ & $1477-1623$ \\
\hline Damiani & GrM-14936 & maize & 280 & 20 & -8.50 & & & $1521-1662$ & $1528-1651$ \\
\hline Damiani & UGAMS-33005 & maize & 295 & 21 & -9.64 & & & $1513-1653$ & $1524-1645$ \\
\hline Damiani & UGAMS-33005r & maize & 272 & 21 & -9.64 & & & $1522-1794$ & $1529-1658$ \\
\hline Damiani & GrM-14937 & maize & 305 & 18 & -8.99 & & & $1511-1646$ & $1524-1641$ \\
\hline Damiani & UGAMS-33006 & maize & 330 & 221 & -8.89 & & & $1300-?$ & 1411-? \\
\hline Damiani & UGAMS-33007 & maize & 311 & 20 & -9.09 & & & $1500-1645$ & $1522-1639$ \\
\hline Damiani & GrM-14938 & maize & 298 & 20 & -9.26 & & & $1512-1650$ & $1524-1644$ \\
\hline $\begin{array}{l}\text { Mackenzie- } \\
\text { Woodbridge }\end{array}$ & UGAMS-40365 & maize & 301 & 21 & -9.00 & 6.86 & & $1506-1650$ & $1524-1643$ \\
\hline $\begin{array}{l}\text { Mackenzie- } \\
\text { Woodbridge }\end{array}$ & UGAMS-434443 & maize & 338 & 21 & -9.49 & & & $1480-1636$ & 1499-1631 \\
\hline $\begin{array}{l}\text { Mackenzie- } \\
\text { Woodbridge }\end{array}$ & UGAMS-40366 & maize & 287 & 20 & -9.66 & 4.20 & & $1520-1658$ & $1526-1650$ \\
\hline $\begin{array}{l}\text { Mackenzie- } \\
\text { Woodbridge }\end{array}$ & UGAMS-34444 & maize & 339 & 21 & -9.82 & & & $1480-1636$ & $1498-1631$ \\
\hline Skandatut & UGAMS-42536 & maize & 350 & 20 & -9.39 & & & $1470-1635$ & $1485-1624$ \\
\hline Skandatut & UGAMS-42540 & maize & 351 & 20 & -10.16 & & & 1467-1635 & $1485-1623$ \\
\hline \multicolumn{10}{|l|}{ DON } \\
\hline Walkington 2 & UGAMS-32989 & maize & 343 & 21 & -9.93 & & & $1476-1636$ & $1493-1631$ \\
\hline Walkington 2 & UGAMS-32990 & unid. botanical & 373 & 21 & -26.57 & & & $1453-1629$ & $1460-1617$ \\
\hline Walkington 2 & GrM-14967 & maize & 359 & 20 & -9.46 & & & $1460-1632$ & $1477-1621$ \\
\hline Walkington 2 & GrM-14968 & maize & 365 & 20 & -8.93 & & & 1457-1631 & $1471-1620$ \\
\hline Baker & GrM-14540 & maize & 377 & 20 & -10.51 & & & $1452-1625$ & $1459-1615$ \\
\hline Baker & UGAMS-32992 & maize & 387 & 21 & -9.31 & & & $1447-1623$ & 1455-1611 \\
\hline Baker & UGAMS-32991 & maize & 364 & 21 & -9.40 & & & $1457-1631$ & $1473-1620$ \\
\hline Baker & GrM-14538 & maize & 387 & 20 & -9.09 & & & $1448-1621$ & $1455-1610$ \\
\hline McNair & GrM-14960 & maize & 316 & 18 & -9.31 & & & $1500-1644$ & $1521-1637$ \\
\hline McNair & UGAMS-32995 & maize & 360 & 21 & -9.70 & & & $1459-1632$ & $1476-1622$ \\
\hline McNair & UGAMS-32994 & maize & 343 & 25 & -10.32 & & & $1475-1636$ & $1492-1631$ \\
\hline McNair & GrM-14961 & maize & 373 & 20 & -9.56 & & & $1455-1625$ & $1460-1617$ \\
\hline HopeN & GrM-14943 & maize & 352 & 18 & -8.88 & & & $1471-1634$ & $1483-1623$ \\
\hline HopeN & UGAMS-32999 & maize & 358 & 21 & -10.22 & & & $1460-1632$ & $1476-1622$ \\
\hline
\end{tabular}


Table 1. Continued.

\begin{tabular}{|c|c|c|c|c|c|c|c|c|c|}
\hline Site & Lab Number & Material & $\begin{array}{c}\text { CRA } \\
{ }^{14} \mathrm{C} \\
\text { Age BP }\end{array}$ & \pm & $\delta^{13} \mathrm{C}$ & ${ }^{15} \mathrm{~N}$ & C:N & $\begin{array}{c}\text { Calibrated } \\
\text { Date Range } \\
95.4 \%\end{array}$ & $\begin{array}{c}\text { Calibrated } \\
\text { Date Range } \\
68.3 \%\end{array}$ \\
\hline HopeN & UGAMS-32998 & maize & 337 & 21 & -9.52 & & & $1481-1636$ & 1499-1632 \\
\hline HopeN & GrM-14944 & maize & 377 & 18 & -8.99 & & & $1453-1624$ & $1459-1615$ \\
\hline HopeS & UGAMS-33000 & maize & 373 & 21 & -9.55 & & & $1453-1629$ & $1460-1617$ \\
\hline HopeS & GrM-14947 & maize & 388 & 17 & -8.48 & & & 1449-1619 & 1456-1607 \\
\hline HopeS & UGAMS-33002 & maize & 393 & 21 & -8.01 & & & $1445-1621$ & $1452-1607$ \\
\hline HopeS & GrM-14948 & maize & 383 & 18 & -7.80 & & & $1451-1621$ & $1457-1611$ \\
\hline Orion & UGAMS-35633 & bone collagen & 330 & 20 & -22.64 & 3.916 & 3.2 & 1490-1639 & $1505-1634$ \\
\hline Orion & UGAMS-35634 & bone collagen & 385 & 19 & -22.08 & 6.603 & 3.3 & $1450-1621$ & $1456-1612$ \\
\hline Murphy-Goulding & UGAMS-34441 & maize & 358 & 21 & -9.68 & & & $1460-1632$ & $1476-1622$ \\
\hline Murphy-Goulding & UGAMS-34442 & maize & 352 & 22 & -9.07 & & & $1460-1635$ & $1481-1623$ \\
\hline Keffer & UGAMS-32997 & maize & 288 & 28 & -12.13 & & & $1504-1662$ & $1524-1651$ \\
\hline Keffer & UGAMS-32997r & maize & 278 & 21 & -12.13 & & & $1521-1792$ & $1528-1653$ \\
\hline Keffer & GrM-14956 & maize & 324 & 20 & -7.96 & & & 1494-1640 & $1515-1635$ \\
\hline Keffer & UGAMS-32996 & maize & 305 & 20 & -9.43 & & & $1506-1648$ & $1524-1641$ \\
\hline Keffer & GrM-14955 & maize & 317 & 18 & -9.48 & & & $1500-1643$ & $1521-1637$ \\
\hline Keffer & UGAMS-26746r & maize & 318 & 20 & -9.58 & & & $1497-1643$ & $1520-1637$ \\
\hline Keffer & UGAMS-26747r & maize & 305 & 20 & -10.17 & & & 1506-1648 & $1524-1641$ \\
\hline Jarrett-Lahmer & UGAMS-40355 & maize & 326 & 20 & -8.52 & & & $1491-1640$ & $1510-1635$ \\
\hline Jarrett-Lahmer & UGAMS-40356 & maize & 298 & 20 & -9.86 & 5.370 & & $1512-1650$ & $1524-1644$ \\
\hline Jarrett-Lahmer & UGAMS-40357 & maize & 272 & 20 & -9.25 & 4.960 & & $1522-1794$ & $1529-1658$ \\
\hline Jarrett-Lahmer & UGAMS-40358 & maize & 322 & 21 & -7.95 & 6.430 & & 1495-1641 & 1516-1636 \\
\hline \multicolumn{10}{|l|}{ TRENT } \\
\hline Jamieson & UGAMS-33014 & maize & 298 & 22 & -9.41 & & & $1507-1653$ & $1524-1644$ \\
\hline Jamieson & GrM-14952 & maize & 353 & 20 & -8.03 & & & $1465-1634$ & $1480-1623$ \\
\hline Jamieson & GrM-14949 & maize & 311 & 18 & -8.60 & & & $1505-1645$ & $1522-1639$ \\
\hline Jamieson & UGAMS-33015 & maize & 334 & 21 & -8.67 & & & $1485-1637$ & $1500-1633$ \\
\hline Kirche & GrM-14957 & unid. botanical & 264 & 20 & -28.76 & & & 1525-1796 & 1636-1661 \\
\hline Kirche & UGAMS-21918 & maize & 285 & 21 & -8.50 & & & $1517-1660$ & $1526-1650$ \\
\hline Kirche & UGAMS-33013 & maize & 315 & 21 & -9.40 & & & $1497-1644$ & $1521-1638$ \\
\hline Kirche & GrM-14958 & maize & 293 & 18 & -9.39 & & & 1519-1653 & $1526-1646$ \\
\hline Coulter & UGAMS-32755 & maize & 307 & 25 & -9.47 & & & 1496-1649 & $1521-1642$ \\
\hline Coulter & UGAMS-32756 & maize & 318 & 25 & -9.31 & & & $1490-1644$ & $1517-1637$ \\
\hline Coulter & UGAMS-32757 & maize & 345 & 25 & -9.28 & & & $1473-1636$ & $1490-1630$ \\
\hline Coulter & GrM-14933 & maize & 276 & 20 & -8.57 & & & $1522-1792$ & $1528-1655$ \\
\hline Coulter & UGAMS-32758 & maize & 313 & 25 & -9.64 & & & $1495-1645$ & $1520-1639$ \\
\hline Coulter & GrM-14934 & maize & 305 & 20 & -9.39 & & & 1506-1648 & $1524-1641$ \\
\hline Coulter & UGAMS-32759 & maize & 323 & 25 & -8.94 & & & $1490-1642$ & $1514-1636$ \\
\hline Coulter & UGAMS-32760 & maize & 296 & 25 & -9.14 & & & $1504-1657$ & $1524-1645$ \\
\hline Coulter & GrM-14548 & maize & 298 & 18 & -9.00 & & & $1516-1650$ & $1524-1644$ \\
\hline Coulter & UGAMS-32761 & hawthorn seed & 330 & 25 & -26.63 & & & $1484-1639$ & $1504-1635$ \\
\hline Coulter & GrM-14928 & hawthorn seed & 391 & 20 & -26.15 & & & $1446-1620$ & $1454-1607$ \\
\hline Coulter & UGAMS-32762 & maize & 309 & 25 & -9.03 & & & $1495-1648$ & $1521-1641$ \\
\hline Coulter & UGAMS-32763 & maize & 362 & 30 & -9.78 & & & $1455-1635$ & $1471-1623$ \\
\hline Coulter & GrM-14931 & maize & 334 & 18 & -8.78 & & & $1490-1637$ & $1505-1632$ \\
\hline Coulter & UGAMS-32764 & maize & 296 & 25 & -9.81 & & & $1504-1657$ & $1524-1645$ \\
\hline Coulter & GrM-14929 & maize & 335 & 18 & -9.16 & & & $1487-1637$ & $1503-1632$ \\
\hline Dawn & UGAMS-33010 & maize & 352 & 21 & -9.59 & & & $1460-1635$ & $1482-1623$ \\
\hline Dawn & GrM-14939 & maize & 347 & 18 & -8.20 & & & 1474-1635 & 1491-1626 \\
\hline Dawn & UGAMS-33011 & maize & 354 & 21 & -8.48 & & & $1462-1634$ & $1480-1623$ \\
\hline Dawn & GrM-14941 & maize & 346 & 20 & -8.71 & & & $1474-1635$ & $1490-1628$ \\
\hline
\end{tabular}

Note: For the complete dataset-including project identification numbers, sample identification to species, taxonomic identification of split and replicate samples, sample provenience, and data for the Warminster, Sopher, Ball, and Benson sites (previously published in Manning et al. 2019)—see Supplemental Table 1 . The $\delta^{13} \mathrm{C},{ }^{15} \mathrm{~N}$, and C values are reported from separate IRMS measurements. 
descendant communities in both Canada and the United States, as well as policies established by the Native American Graves Protection and Repatriation Act (USA), no materials from burials or burial contexts were sampled.

Preference for sample selection was given to carbonized maize, followed by other short-lived annuals (beans, seeds, nutshells, etc.), followed by herbivore animal bone such as deer or other fauna known to follow a nonaquatic diet. All bone was identified to the taxonomic level of species. In some cases, the nature of collections from sites included the possibility of residual and/or more recent material being sampled. In those cases, the derived dates were used to exclude samples deemed too old or too recent.

\section{Radiocarbon Dating}

AMS ${ }^{14} \mathrm{C}$ dates were obtained from two laboratories-the Center for Applied Isotope Studies (CAIS) at the University of Georgia and the Center for Isotope Research (CIO) at the University of Groningen. These included a number of split, or replicate, samples to establish that similar results were achieved independent of the individual laboratory (Supplemental Table 1). See Supplemental Material for sample pretreatment and lab methods as well as discussion of the comparability of replicate samples, which were found to be good.

\section{Bayesian Modeling}

Calibration and Bayesian chronological modeling used the OxCal software (version 4.4.1 [2020]; Bronk Ramsey 2009a, 2009b), forms of outlier analysis (Bronk Ramsey 2009b; Dee and Bronk Ramsey 2014; Dee et al. 2013), and the IntCal20 ${ }^{14} \mathrm{C}$ calibration dataset (Reimer et al. 2020), with curve resolution set at one year. We employ capitalized forms of words such as Sequence, Phase, Boundary, Date, Interval, Span, and Order to refer to OxCal Chronological Query Language (CQL2) Command Reference terms.

Because the historical contingencies within each site relocation sequence were unique, each was modeled using parameters that best fit current archaeological understandings of those local sequences (supplemental materials for site data and models, including variations on select parameters, as well as discussion in Results are below). We recognize that this means that our assessments of the chronology are not fully independent of other assumptions within each sequence, although each sequence is independent of the others. Consequently, in contrast with previous efforts where we sought to employ the radiocarbon evidence as an entirely independent temporal arbiter or indicator (Manning et al. 2018), here we have necessarily incorporated best current archaeological assessments, and so there is an element of circularity. As a result, the plausibility of a model suggests that it is possible (i.e., all interpretative hypotheses are consistent with the data and constraints available), but with the caveat that by itself it cannot offer entirely independent confirmation of those assumptions. We acknowledge that the assumption of temporal order from this archaeological knowledge is key to the results we obtain (and resolution of the ambiguities otherwise caused by the plateau in the calibration curve). We discuss this issue in the Supplemental Material.

All single-component sites were modeled as Phases. We assume that the dates in a Phase are random examples from a uniform probability distribution, because we have no reason to assume otherwise (e.g., the data do not come from either end-of-Phase destructions or foundation deposits but rather from the random processes of human presence across the few decades of each site and Phase in total). Where internal phasing existed due to village expansion, we considered a Sequence with each component modeled as a Phase. Date estimates were calculated as a summary of each Phase. The Date function in OxCal determines a hypothetical event describing the temporal extent of the Phase between its start and end Boundaries. The Interval function was employed to estimate the duration of each Phase between its start and end Boundaries (in contrast, the Span query quantifies the time period between the first and last dated elements within a Phase, or other parent group). Where we have only a few data and no way to judge whether these are in fact representative of the overall Phase, and yet seek a conservative overall site duration estimate, the Interval query offers the best-or rather, safest (i.e., longer, conservative)-guide. Where we have more 
data and especially evidence from a range of a site's history, then the available dates may be considered more representative, so a Span query can be considered to indicate approximate Phase duration (e.g., Manning et al. 2018). Where we have closely spaced Phases arranged in a contiguous Sequence, then the before and after constraints within the Sequence restrict the Boundary distributions and Phase duration estimates, and both Interval and Span queries give more similar values.

A key element of prior, expert knowledge for estimating the dates of Iroquoian site Phases in the period we address is the understanding from ethnohistoric reports and archaeological analysis that such village sites were occupied for between approximately 0 and 40 years. As noted before (e.g., Manning and Hart 2019; Manning et al. 2019), however, with no additional constraint, Interval queries applied to models employing the radiocarbon dates available will, to the contrary, often estimate much longer possible durations (and especially across the 1480-1620 plateau in the calibration curve). We therefore apply a prior constraint to an Interval query for each site Phase. Following the discussion in Manning and others (2020), we employ a prior using a LnN distribution: $\operatorname{LnN}(\ln (20), \ln$ (2)) (for the shape of the probability distribution, see Supplemental Figure 1a). This prior probability distribution gives a peak probability for around a 5-20-year site duration, with much--reduced probability after 40 years-but it allows for a few possible exceptions. (A benefit of a $\mathrm{LnN}$ prior, versus a Uniform prior, is that if the data indicate otherwise, then they can overwhelm the prior.) This prior reflects reasonably the expert knowledge available (see above). It appears slightly better than a Normal Distribution (e.g., $20 \pm 10$ years) for any single settlement since (1) it places higher probability more to the earlier end of the ranges (e.g., 5-20 years) rather than in the middle of the range, since the ethnohistoric evidence suggests durations typically more in the 10-20-year range, and less than 30-40 years (see above); and (2) it better allows for possible longer-lived exceptions. To illustrate the effect of this prior, we can consider the Middle Humber case. With no such extra constraint, both sites in this model give over-long Interval ranges (Black Creek, Parsons; see Supplemental Figure 1b). Applying the above Interval constraint, however, the two site Phase Intervals are constrained to be more appropriate in length given the expert knowledge available (Supplemental Figure 1c). See further discussion in the Supplemental Material.

The estimated Dates and Intervals for each site and component are listed in Table 2. Unless otherwise indicated, estimated Dates for each site (constructed as one or more Phases) are discussed as "interpretative" $68.3 \%$ highest posterior density (hpd) intervals in the text below, with the conservative $95.4 \%$ hpd intervals provided in Table 2, along with any subranges. Where there are subranges, we sometimes cite a clearly more likely subrange in the text. It should be noted that results from different $\mathrm{OxCal}$ runs can vary slightly. We list the Convergence (C) values for the elements in each model in Supplemental Figures 2-7, all $\geq 95$, to illustrate that the models are robust (and where ambiguity remains, it is robust ambiguity).

\section{Results}

\section{Humber Valley}

Differences in ceramic assemblages suggest that two distinct community groups occupied the Humber Valley in the Late Woodland period (Figure 4). In the Middle Humber Valley, at least two small villages, including the Black Creek site, coalesced at the Parsons site (Williamson and Robertson 1995). There are three sites in the Upper Humber River valley previously thought to date to the late fifteenth to midsixteenth century: Damiani, Seed-Barker, and Mackenzie-Woodbridge. All are palisaded, and their sizes suggest that they were the product of settlement aggregation, although the temporal relationships between each is not clear, and this is reflected in the model parameters. SeedBarker and Mackenzie-Woodbridge were both found to contain small amounts of European metal (Emerson 1954; Fox et al. 1995). Skandatut is another large palisaded village that has been assumed as the latest in the sequence on account of nine pieces of European metal identified from limited excavations in the village 
Table 2. Date and Interval Estimates of Sites as per Modeled Site Sequences.

\begin{tabular}{|c|c|c|c|c|c|}
\hline Site & Previous Age Estimate & Date $(68.3 \%)$ & Date $(95.4 \%)$ & $\begin{array}{l}\text { Interval } \\
(68.3 \%)\end{array}$ & $\begin{array}{l}\text { Interval } \\
(95.4 \%)\end{array}$ \\
\hline \multicolumn{6}{|c|}{ Middle Humber (Humber Model $\left.A_{\text {model }} 90.3, A_{\text {overall }} 102.3\right)$} \\
\hline Black Creek & $1400-1450$ & $\begin{array}{c}1475-1614 \\
1476-1503(53.1 \%) \\
1602-1614(15.1 \%)\end{array}$ & $\begin{array}{c}1458-1622 \\
1458-1517(67.0 \%) \\
1583-1622(28.5 \%)\end{array}$ & $5-24$ & $2-48$ \\
\hline Parsons & $1450-1500$ & $\begin{array}{c}1495-1627 \\
1495-1523(52.8 \%) \\
1616-1627(15.4 \%)\end{array}$ & $\begin{array}{c}1480-1639 \\
1480-1539(66.6 \%) \\
1597-1639(28.9 \%)\end{array}$ & $5-22$ & $2-44$ \\
\hline \multicolumn{6}{|c|}{ Upper Humber (Humber Model $\left.A_{\text {model }} 90.3, A_{\text {overall }} 102.3\right)$} \\
\hline Seed-Barker & $1500-1550$ & $\begin{array}{c}1506-1574 \\
1506-1535(43.1 \%) \\
1550-1574(25.2 \%)\end{array}$ & $1494-1589$ & $5-31$ & $3-63$ \\
\hline Damiani (core) & & $1526-1545$ & $1518-1559$ & $0-11$ & $0-27$ \\
\hline Damiani (expansion) & $1480-1510$ & $1533-1553$ & $1528-1569$ & $0-11$ & $0-26$ \\
\hline Mackenzie-Woodbridge & $1500-1550$ & $1522-1563$ & $1507-1583$ & $5-26$ & $2-52$ \\
\hline Skandatut & $1580-1600$ & $1599-1629$ & $1579-1639$ & $5-23$ & $2-44$ \\
\hline \multicolumn{6}{|c|}{ Don Valley $\left(A_{\text {model }} 163.4, A_{\text {overall }} 165.6\right)$} \\
\hline Walkington 2 & $1400-1450$ & $1483-1504$ & $1471-1519$ & $5-20$ & $3-33$ \\
\hline Baker & $1400-1450$ & $1476-1498$ & $\begin{array}{c}1462-1607 \\
1462-1511(95.0 \%) \\
1605-1607(0.5 \%)\end{array}$ & $5-19$ & $3-32$ \\
\hline McNair & $1400-1450$ & $1488-1510$ & $1474-1523$ & $5-20$ & $3-33$ \\
\hline Hope (North) & & $1482-1500$ & $1472-1512$ & $4-13$ & $2-20$ \\
\hline Hope (South) & $1400-1450$ & $1480-1498$ & $\begin{array}{c}1469-1607 \\
1469-1509(95.1 \%) \\
1605-1607(0.4 \%)\end{array}$ & $4-13$ & $2-20$ \\
\hline Orion-Murphy Goulding & $1400-1450$ & $1485-1506$ & $1471-1520$ & $5-20$ & $3-34$ \\
\hline Keffer & $1450-1510$ & $1527-1549$ & $\begin{array}{c}1519-1637 \\
1519-1568(93.9 \%) \\
1632-1637(1.6 \%)\end{array}$ & $5-18$ & $2-33$ \\
\hline Jarrett-Lahmer & $1450-1500$ & $1526-1548$ & $\begin{array}{c}1518-1638 \\
1518-1568(93.7 \%) \\
1632-1638(1.8 \%)\end{array}$ & $5-19$ & $2-34$ \\
\hline \multicolumn{6}{|c|}{ Trent Valley $\left(A_{\text {model }} 108, A_{\text {overall }} 117\right)$} \\
\hline Jamieson & $1450-1500$ & $1504-1535$ & $1485-1562$ & $6-40$ & $3-85$ \\
\hline Kirche (early) & & $1525-1537$ & $1517-1546$ & $0-13$ & $0-27$ \\
\hline Kirche (late) & $1500-1550$ & $1531-1544$ & $1528-1553$ & $0-8$ & $0-17$ \\
\hline Coulter (core) & & $1515-1532$ & $1509-1546$ & $0-8$ & $0-21$ \\
\hline Coulter (exp 4) & $1500-1550$ & $1540-1558$ & $1535-1572$ & $0-2$ & $0-5$ \\
\hline Benson (early) & & $1528-1546$ & $1521-1557$ & $0-10$ & $0-22$ \\
\hline Benson (late) & $1550-1600$ & $1536-1556$ & $1528-1568$ & $0-10$ & $0-24$ \\
\hline Dawn & $1500-1600$ & $\begin{array}{c}1505-1604 \\
1505-1521(18.7 \%) \\
1571-1604(49.6 \%)\end{array}$ & $\begin{array}{c}1491-1616 \\
1491-1530(30.1 \%) \\
1552-1616(65.4 \%)\end{array}$ & $5-23$ & $2-45$ \\
\hline Sopher & $1550-1600$ & $1540-1567$ & $1527-1582$ & $5-21$ & $3-37$ \\
\hline Ball & $1590-1615$ & $\begin{array}{c}1570-1620 \\
1570-1601(67.6 \%) \\
1620(0.6 \%)\end{array}$ & $1563-1628$ & $5-21$ & $3-40$ \\
\hline Warminster & $1600-1625$ & $1603-1630$ & $1583-1637$ & $5-26$ & $3-50$ \\
\hline \multicolumn{6}{|c|}{ Seneca $\left(A_{\text {model }} 132.4, A_{\text {overall }} 133.4\right)$} \\
\hline Farrell & $1350-1450$ & $1399-1416$ & $1391-1427$ & $5-23$ & $3-42$ \\
\hline Footer & $1350-1400$ & $1461-1482$ & $1453-1493$ & $5-20$ & $3-35$ \\
\hline Belcher & $1500-1550$ & $1491-1516$ & $1478-1528$ & $5-23$ & $3-41$ \\
\hline Richmond Mills & $1500-1550$ & $1503-1523$ & & $5-22$ & $3-40$ \\
\hline
\end{tabular}


Table 2. Continued.

\begin{tabular}{|c|c|c|c|c|c|}
\hline Site & Previous Age Estimate & Date $(68.3 \%)$ & Date $(95.4 \%)$ & $\begin{array}{l}\text { Interval } \\
(68.3 \%)\end{array}$ & $\begin{array}{l}\text { Interval } \\
(95.4 \%)\end{array}$ \\
\hline & & & $1487-1565$ & & \\
\hline & & & $1487-1536(94.0 \%)$ & & \\
\hline & & & $1557-1565(1.5 \%)$ & & \\
\hline Tram & $1580-1600$ & $1553-1584$ & $1535-1594$ & $7-36$ & $4-59$ \\
\hline Cameron & $1590-1610$ & $1580-1601$ & $1567-1610$ & $6-23$ & $3-40$ \\
\hline Factory Hollow & $1600-1620$ & $1597-1617$ & $1587-1628$ & $5-21$ & $3-38$ \\
\hline \multicolumn{6}{|c|}{ Alhart $\left(A_{\text {model }} 133.2, A_{\text {overall }} 129.3\right)$} \\
\hline \multirow[t]{3}{*}{ Alhart } & $1440-1510$ & $1524-1566$ & $1514-1644$ & $5-26$ & $2-51$ \\
\hline & or $1525-1550$ & & $1514-1586(83.9 \%)$ & & \\
\hline & & & $1621-1644(11.5 \%)$ & & \\
\hline \multicolumn{6}{|c|}{ Onondaga $\left(A_{\text {model }} 112.2, A_{\text {overall }} 120.2\right)$} \\
\hline Kelso & 1390 & $1399-1417$ & $1390-1430$ & $5-20$ & $2-38$ \\
\hline Howlett Hill & 1380 & $1418-1437$ & $1406-1444$ & $5-21$ & $3-36$ \\
\hline Schoff & 1410 & $1433-1451$ & $1424-1460$ & $5-19$ & $3-32$ \\
\hline Bloody Hill & $1400-1450$ & $1463-1485$ & $1452-1494$ & $6-24$ & $3-39$ \\
\hline Christopher & $1420-1450$ & $1488-1506$ & $1479-1513$ & $4-14$ & $2-23$ \\
\hline Burke & 1480 & $1487-1504$ & $1479-1511$ & $4-14$ & $2-23$ \\
\hline Cemetery & $1450-1500$ & $1508-1523$ & $1499-1529$ & $5-17$ & $3-27$ \\
\hline Barnes & $1500-1525$ & $1524-1540$ & $1517-1551$ & $4-13$ & $2-22$ \\
\hline $\mathrm{McNab}$ & $1500-1525$ & $1526-1540$ & $1520-1551$ & $4-13$ & $2-22$ \\
\hline Temperance House & $1525-1550$ & $1545-1568$ & $1537-1580$ & $4-15$ & $2-27$ \\
\hline Atwell & $1525-1550$ & $1546-1569$ & $1538-1581$ & $4-16$ & $2-27$ \\
\hline Chase & $1575-1600$ & $1574-1606$ & $1556-1614$ & $5-27$ & $3-47$ \\
\hline \multirow[t]{3}{*}{ Pompey Center } & $1600-1620$ & $1619-1639$ & $1570-1647$ & $5-20$ & $2-37$ \\
\hline & & & $1570-1596(11.2 \%)$ & & \\
\hline & & & $1608-1647(84.2 \%)$ & & \\
\hline
\end{tabular}

Note: See Supplemental Tables 3-8 for model specifications. Supplemental Table 9 includes an Order analysis for the Don Valley sequence. Supplemental Figures 8-12 and Supplemental Tables 10-12, 14-15 consider variations on the modeling parameters, including the effects of incorporation of prior archaeological knowledge. Supplemental Table 13 lists the start and end Boundaries for each site. Rounding errors mean that probabilities, when there are sub-ranges, sometimes add up to $0.1 \%$ more, or less, than the stated $68.3 \%$ and $95.4 \%$.

area (Williamson 2014:25). Skandatut is also associated with the Kleinberg Ossuary that was found to contain a sizable assemblage of European-derived grave goods-including early-style iron trade axes, an iron kettle, shell beads, native copper beads, and a large quantity of glass trade beads-leading to the site being assigned a relative date of $1580-1600$ (ASI 2012).

Middle Humber. When modeled as a Sequence the data indicate that Black Creek dates to $1475-1503(53.1 \%$ of the $68.3 \% \mathrm{hpd})$ and Parsons to $1495-1523 \quad(52.8 \%$ of the $68.3 \% \mathrm{hpd})$. This places the precoalescent Black Creek site as being occupied in the later fifteenth to early sixteenth century, as opposed to the previous age estimate of 1400-1450, pushing the site well into what has been understood as the period of widespread community coalescence. Parsons then dates somewhat later than its previous age estimate of 1450 1500. Both sites are palisaded, and Parsons contained more than a thousand scattered skeletal elements (Williamson 2007), suggesting involvement in the hostilities that characterized the later Woodland period.

Upper Humber. Modeled Date estimates for these sites indicate an early to mid-sixteenthcentury occupation for Seed-Barker (1506-1535, $43.1 \%$ of the $68.3 \%$ hpd), Mackenzie-Woodbridge (1522-1563), and Damiani (15261553). The lack of European goods and presence of human remains in midden contexts at Damiani has led some to assume that it may have been in the earlier portion of the local sequence (ASI 2015), but that does not seem to have been the 


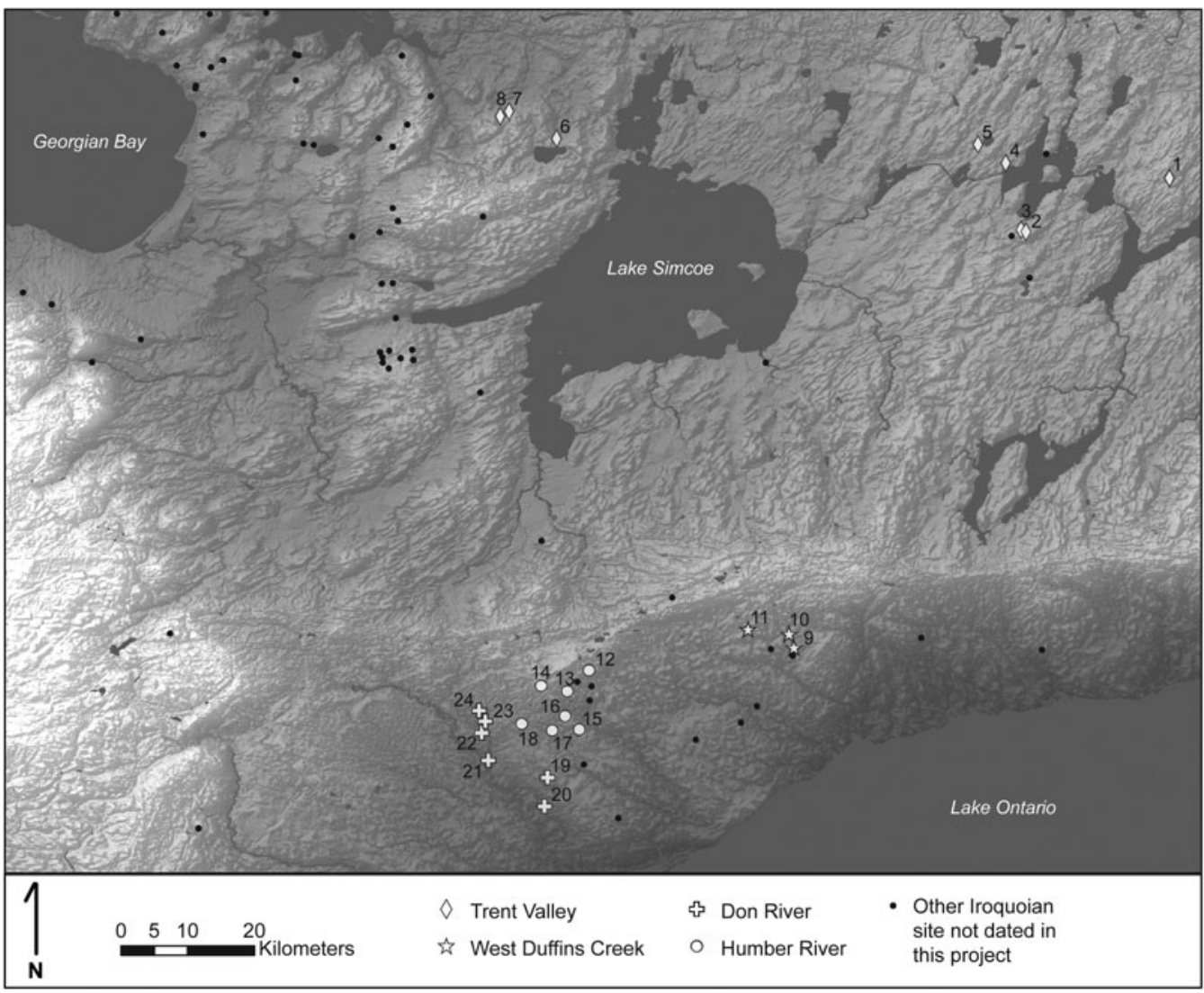

Figure 4. Map of Wendat site sequences, with dated and undated sites indicated. Dated sites are numbered. Trent Valley: (1) Dawn, (2) Kirche, (3) Jamieson, (4) Coulter, (5) Benson, (6) Sopher, (7) Warminster, (8) Ball; West Duffins Creek: (9) Draper, (10) Spang, (11) Mantle; Don River Valley: (12) Orion-Murphy-Goulding, (13) McNair, (14) Hope, (15) Baker, (16) Walkington 2, (17) Keffer, (18) Jarrett-Lahmer; Humber River Valley: (19) Parsons, (20) Black Creek, (21) Mackenzie-Woodbridge, (22) Seed-Barker, (23) Skandatut, (24) Damiani. Basemap: United States Geological Survey 2017. Waterways and inset basemap: Natural Earth 2019.

case. Skandatut now has an estimated Date of 1599-1629-somewhat later than has been previously assumed and coincident with documented direct European contact farther north and east (e.g., Biggar 1929-1936). Even when the $95.4 \%$ confidence interval is considered (15791639), the new date estimate for the Skandatut site creates a gap of some roughly 5-20 years between its occupation and the occupation of those sites believed to predate it in the local sequence (but see Supplemental Table 12 for modeled Boundaries for each site occupation, which serve to close this gap somewhat). Since it is unlikely that there are undiscovered sites located in the Upper Humber Valley, this may be an artifact of the small sample size available for most of these sites such that the dates do not represent the full occupational span of each (see Table 1; Supplemental Table 1). The small sample of material culture available for Skandatut, owing to its history of investigation, hampers further investigation of this disparity in date ranges. Nevertheless, these data, together with the understanding that sites in the West Duffins drainage were occupied longer than previously assumed, suggest that the north shore of Lake Ontario may have continued to be occupied later than 1610. This date has been referenced as marking the abandonment of the north shore region by Huron-Wendat, based on assumptions derived from ethnohistoric accounts (e.g., Trigger 1976:244). 


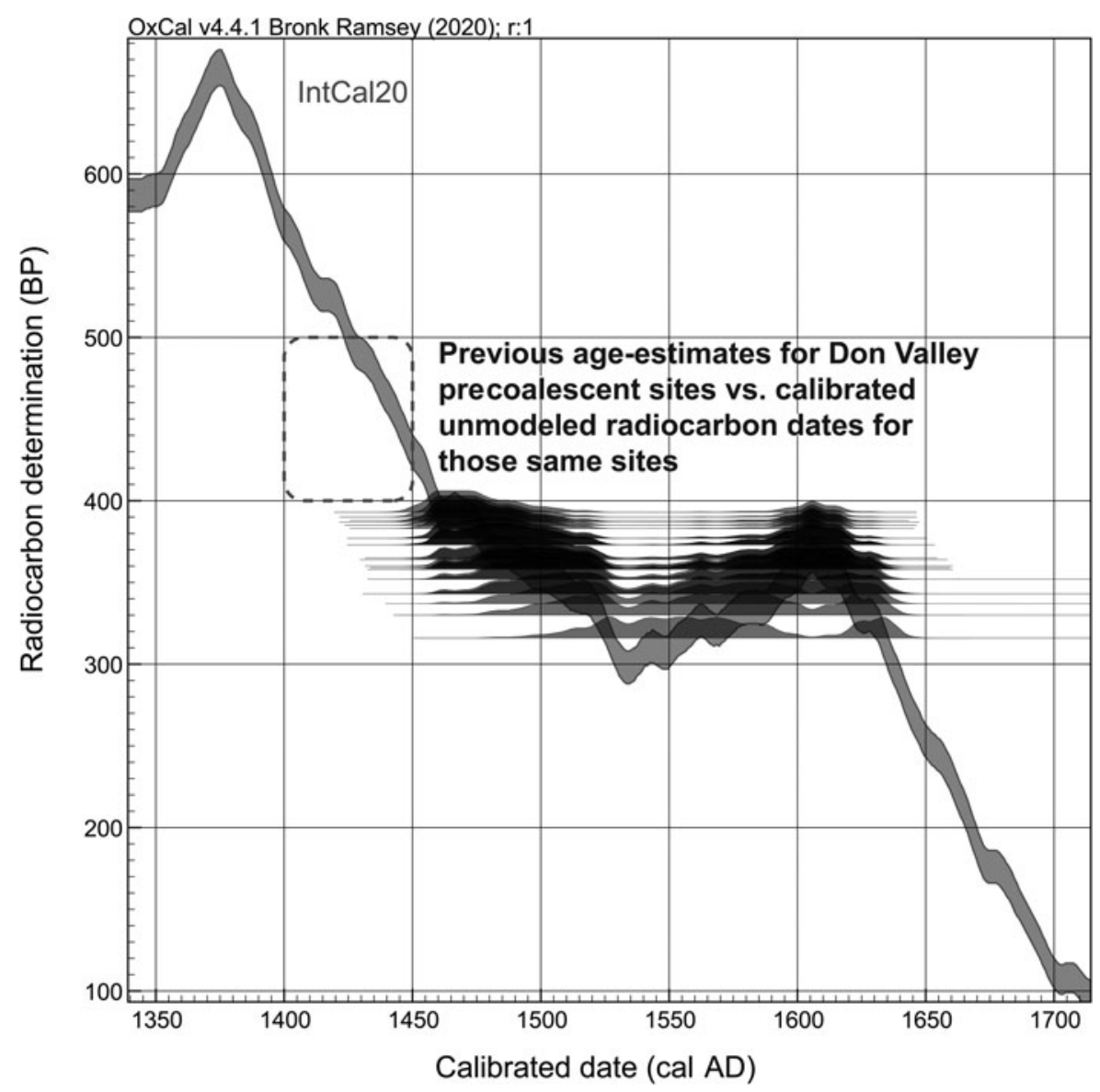

Figure 5. Calibrated, unmodeled radiocarbon dates for Don Valley precoalescent sites, $95.4 \%$ hpd range indicated. All were previously thought to date to AD 1400-1450 and now can be shown to postdate that period.

\section{Don River Valley}

In the Don River Valley, there are at least 15 small village sites assumed to date to the fifteenth and sixteenth centuries (Birch and Williamson 2013), seven of which were dated for this study (Figure 4; Supplemental Table 2). It has been assumed that at least some of the smaller, unpalisaded sites came together to form the larger Keffer site. It seems likely that another palisaded site in the valley, Jarrett-Lahmer, may have been at least partly contemporary with Keffer. None of these sites was found to contain European materials. An Order query applied to the precoalescent grouping of six sites (with each of the Hope site components considered separately) shows the following likely order (oldest to most recent-but also with some likely substantial overlaps): Baker, Hope South,
Hope North, Walkington, Orion-Murphy Goulding, McNair (Supplemental Table 9). This order fits within an overall precoalescent Phase estimated to last about $30-57$ years $(68.3 \% \mathrm{hpd})$ or $21-76$ years $(95.4 \% \mathrm{hpd})$. It is likely several sites overlapped to some extent (especially Hope South and Hope North and Walkington and OrionMurphy Goulding). An Order query applied to the two coalescent sites, Keffer and Jarrett-Lahmer, does not indicate a clear order ( $p=0.52$ JarrettLahmer older), and the sites may well be approximately contemporary.

Previous assumptions held that none of the unpalisaded sites in the Don Valley postdated 1450. Our results, however, indicate that none of these sites predates 1450 (Table 2). Even when all dates from these sites are calibrated 
with no additional constraints, the earliest dates calibrate to a start date of not before 1445 (95.4\%; Figure 5). When modeled, the earliest Date estimates for precoalescent site occupations start at 1476-1498 and end at 1488-1510, some 75-100 years later than previously assumed. The effect of these data alone requires the rejection of the inference that conflict on the north shore of Lake Ontario was widespread around 1450, as has previously been assumed (Birch 2012; Birch and Williamson 2013).

The Keffer and Jarrett-Lahmer sites both produced almost identical Date estimates of 15271549 and 1526-1548. When modeled as Phases in isolation with no other constraints, Keffer dates to a very similar range of $1527-1560$ as does Jarrett-Lahmer (1524-1560, 63.3\% of the $68.3 \%$ hpd). Before now, it has been unclear where Jarrett-Lahmer should be placed in the local sequence: before, after, or concurrent with Keffer (Birch and Williamson 2013). Our data suggest that Jarrett-Lahmer may have been occupied concurrently with Keffer, but they do not rule out a sequential relationship between the two sites, although the smaller size of Jarrett-Lahmer makes it unlikely that it could accommodate the same population.

\section{Trent Valley}

The local sequence in the Upper Trent Valley has been the subject of extensive study by Peter Ramsden and colleagues, resulting in the documentation of multiple village sites thought to span the late fifteenth through late sixteenth centuries (e.g., Damkjar 2009; Nasmith 2008; Ramsden 2009, 2016; Figure 4). This local sequence is understood to represent the genesis of the Wendat Arendarhonon Nation (Trigger 1976) and to have potentially involved the incorporation of eastern Iroquoian and Anishinaabeg peoples (Ramsden 2009, 2016). A historical and radiocarbon intersection for this sequence exists with Samuel de Champlain's likely 1615-1616 stay at the Warminster site (Manning et al. 2018, 2019). This model incorporates dates from the Jamieson, Kirche, Coulter, Benson, Dawn, Sopher, and Ball sites. Short-lived botanical samples and a series of rings on a preserved tamarack (Larix laricina) post from the Warminster site (as per Manning et al. 2018, 2019) serve as a TAQ for the sequence.

Current archaeological understandings of the Trent Valley sequence, based on multiple lines of material evidence-including ceramic seriation, the appearance of material culture indicative of populations originating in the St. Lawrence Valley to the east, and the presence or absence of European metals-were used to inform the parameters of the model (as per Ramsden 2009, 2016). Jamieson has been thought to be the earliest-known Iroquoian village site in the present study and is thought to date to the mid to late fourteenth century. Kirche is thought to have been at least partly contemporary with Jamieson. At some point during Kirche's occupation, an additional cluster of longhouses was added outside the palisaded village core. Ramsden (2016) suggested that the Coulter village core might have been established at the same time that Kirche was occupied. Coulter then went on to expand five times. Benson was thought to be among the latest sites in the sequence. St. Lawrence-associated pottery and fragments of European metal (but no glass beads) have been recovered from the Kirche site expansion, Coulter, and Benson. Dawn is the least-known site in the upper Trent Valley, but it has one of the highest percentages of eastern pottery types, suggesting a later date in the sequence. Where sites included expansions or early and later phases of occupation, that information was also used in the model construction (e.g., Damkjar 2009; Ramsden 2009).

Modeled Date estimates for the Trent Valley suggest a significant degree of overlap between site occupations. The modeled age estimate for the Jamieson site is 1504-1535, coincident with evidence for the onset of conflict on the north shore of Lake Ontario to the west. The early phase of occupation at Kirche is estimated to date to $1525-1537$, with the later addition of houses outside the palisade occurring between 1531 and 1544 . The establishment of the Coulter village core is estimated between 1515 and 1532 , with the final phase of village expansion occurring between 1540 and 1558 . The Benson village early phase is estimated to have been occupied from 1528 to 1546 , with a portion of the houses then abandoned and the remainder continuing to 
be occupied until approximately 1536-1556. Dawn most likely dates to 1571-1604 (49.6\% of the $68.3 \% \mathrm{hpd}$ ). Sopher is estimated to date to $1540-1567$, Ball $1570-1601 \quad(67.6 \%$ of $68.3 \% \mathrm{hpd}$ ), and Warminster 1603-1630 (see alternative model results in Supplemental Table 9). These Date estimates are very similar to those reported in Manning and others (2019; see Supplemental Table 14).

Although the dates for the Trent Valley model do not diverge significantly from what was previously thought about this sequence and indeed incorporate some of those assumptions, the modeled Date estimates suggest that the sites of Kirche, Coulter, Benson, and Sopher may have all been at least partly contemporaneous in the mid-sixteenth century. This suggests that the area was home to a substantial local population and that it corresponds with ethnohistoric accounts of the Arendarhonon being a populous nation (Trigger 1976). It also concurs with understandings about an influx of population from both the east and west in the early to mid-sixteenth century (Ramsden 2016). Although it is possible that Dawn was occupied until the turn of the seventeenth century, the majority of the Trent Valley population may have left the valley before approximately 1560 . Ethnohistoric references indicate that the Arendarhonon joined the Wendat Confederacy in about 1590 (Thwaites 18961901:16:227-229), postdating Sopher's entire occupation and the establishment of Ball village. These data suggest that more complex or prolonged processes of population movement and alliance building may have taken place in eastern Wendake than has previously been assumed.

\section{Seneca}

In New York State, researchers have been somewhat more cautious about assigning dates to sites prior to the arrival of European diagnostic trade goods. This caution derives from limited sitelevel settlement pattern data and the relatively small sizes of material assemblages, although generalized sequences have been constructed for each subregion (Figure 6; Bradley 2005; Engelbrecht 2003; Sempowski and Saunders 2001; Tuck 1971; Wray and Schoff 1953).

The early portion of the Seneca model was constructed as a Sequence of noncontiguous site occupations. Farrell and Footer are small village sites that were dated to provide a terminus post quem for the later portion of the sequence, which includes the Belcher, Richmond Mills, Tram, Cameron, and Factory Hollow sites. The latter three have been hypothesized as representing sequential iterations of the same village occupied by the Eastern Seneca (Sempowski and Saunders 2001; Wray et al. 1991). The nonSeneca Alhart site, located immediately north of Seneca traditional territory, bears on the timing of regional conflict.

\section{Earlier Seneca Sequence}

Farrell and Footer have been loosely estimated to date to approximately 1300-1350 and 13501450, respectively (Engelbrecht 2001 [1981]; Niemczycki 1984). The new Date estimates suggest that each, in fact, dates somewhat later and noncontiguously, with Farrell estimated to have been occupied from 1399 to 1416 and Footer from 1461 to 1482. This shifts the occupation of each site 50 100 years later than previous interpretations, and it may have implications for understandings of early settled village life in this subregion.

Belcher and Richmond Mills are among the first larger village sites in the Seneca region, and they have been postulated as being the start of the eastern and western Seneca sequences (Niemczycki 1984; Wray et al. 1987). Although little is known about Belcher, one decapitated skull was reported as being uncovered in the burial area. Richmond Mills was reported as containing charred human remains (Parker 1918:8) and small amounts of European metal. Our model, with no assumed order between the two, places Belcher at 1491-1516, slightly earlier than Richmond Mills's Date estimate of 1503-1523. This is more or less in keeping with the early sixteenth-century dates assumed for both sites.

\section{Alhart}

The non-Seneca Alhart site is located some 50 $\mathrm{km}$ north of Seneca territory. The burning of the village and 15 male skulls found in a pit have been interpreted as evidence of violent conflict (Hamell 1977; Niemczycki 1984; Wray et al. 1987). Biodistance markers suggest that Alhart females may have been incorporated 


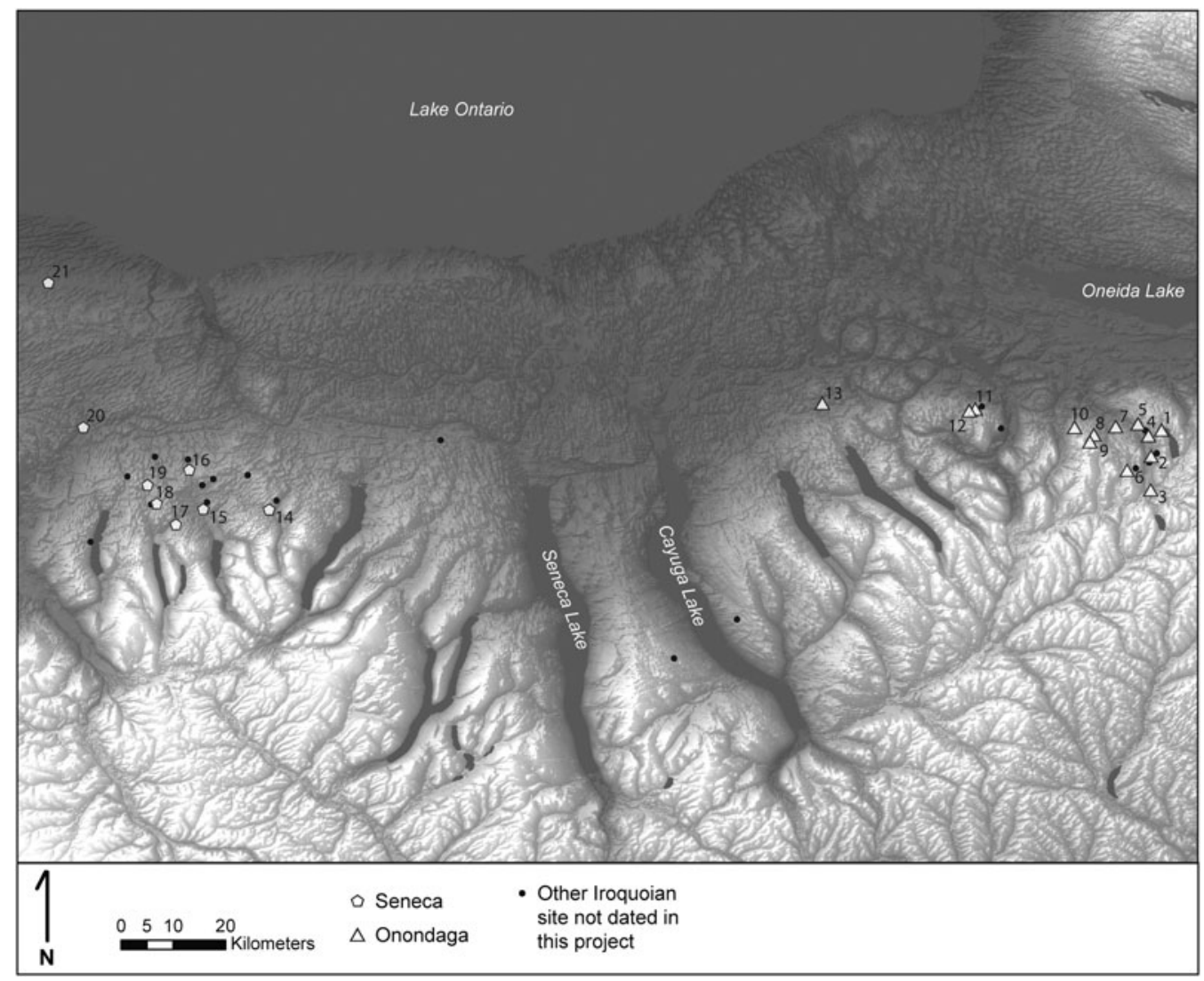

Figure 6. Map of Haudenosaunee site sequences, with dated and undated sites indicated. Dated sites are numbered. Onondaga: (1) McNab, (2) Atwell, (3) Chase, (4) Temperance House, (5) Barnes, (6) Pompey Center, (7) Cemetery, (8) Christopher, (9) Burke, (10) Bloody Hill, (11) Howlett Hill, (12) Schoff, (13) Kelso; Seneca: (14) Footer, (15) Belcher, (16) Factory Hollow, (17) Richmond Mills, (18) Tram, (19) Cameron, (20) Farrell, (21) Alhart. Basemap: United States Geological Survey 2017. Waterways and inset basemap: Natural Earth 2019.

into the Seneca Adams site population (Wray et al. 1987:248). The community may have been related to populations from further west that were subsequently driven out, destroyed, or absorbed by the Seneca (Engelbrecht 2003:115; Hamell 1977). Dates on short-lived botanicals from this site modeled in isolation from the rest of the sequence suggest a Date range of 1524 1566.

\section{Later Seneca Sequence}

Samples for the Tram, Cameron, and Factory Hollow sites were obtained for the later eastern Seneca sequence. We lack data for the Adams and Culbertson sites that presumably link the earlier and later parts of the eastern and western sequences. One of the challenges we faced in sampling was the avoidance of material from burial contexts, which comprises a large portion of curated Seneca assemblages. Although no dates are available from these sites, it should be noted that at Adams, a large, roughly rectangular palisade enclosing 4 ha was mapped by Squier in 1848 and archaeologically identified, together with male skeletons excavated from the cemeteries that show evidence of combat trauma in the form of "parry fractures" (Wray et al. 1987:13, 31-21). Both Adams and Culbertson are located on hilltops, suggesting a concern for defensive siting.

A postulated sequence of relocations was constructed as Tram to Cameron to Factory Hollow, with some question about Cameron's place in either the eastern or western sequences, or 
possible partial contemporaneity with Factory Hollow (Sempowski and Saunders 2001; Wray et al. 1991). Our results are more or less in keeping with the most recent "revised" sequence presented by Sempowski and Saunders (2001): Tram, 1553-1584; Cameron, 1580-1601; and Factory Hollow, 1597-1617. Evidence for conflict continues to be apparent in these later sites: Tram was a reportedly fortified village that also included an earthwork (Wray et al. 1991), and Cameron is not only heavily palisaded but also has a mortuary population that includes evidence of violent death (Engelbrecht 2003; Wray et al. 1991). No palisade has been identified at Factory Hollow, although it is located on a steep promontory.

\section{Onondaga}

The Onondaga settlement pattern is characterized by pairs of large and small villages, and these were used to construct a sequence of paired sites that the model assumed to be roughly contiguous (Figure 6; Bradley 2005; Tuck 1971). Few of these have been subject to extensive or professional investigation. A robust independent testing program is hampered by the small collections and lack of documentation for many sites in the Onondaga sequence. For example, only one sample per site was available for dating from the Howlett Hill, Schoff, Christopher, and Barnes sites (Table 1). These small sample sizes also have the result of over-constraining Interval estimates for the occupation of each site (Table 2).

The earliest Onondaga sites we dated are Kelso, Howlett Hill, and Schoff. These were modeled with the inferred relocation of Howlett Hill to Schoff as per Tuck's understanding of the sequence. The model placed Kelso at 13991417, Howlett Hill at 1418-1437, and Schoff at 1433-1451. Whereas Kelso is dated only slightly later than Tuck's estimate, Howlett Hill and Schoff are placed some 20-40 years later.

Next, Bloody Hill produced a Date estimate of 1463-1485, some 40 years later than previously assumed. A roasting pit at the Bloody Hill site was found to contain numerous fragments of human bone interpreted by Tuck (1971:113114) as evidence for cannibalism.
The Burke site, which follows Bloody Hill, is defensively located and heavily palisaded. Our models place the Burke and Christopher sites in a Phase spanning 1487-1504. These sites are followed in the sequence by the Cemetery site at 1508-1523. The Cemetery village occupies a location on a triangular peninsula that drops off very sharply to the east and west and appears to have been selected for its defensibility (Tuck 1971:141).

The McNab site is one of the largest in the Onondaga sequence, and the assumption is that it represents a coalescent village. In our model, the $\mathrm{McNab}$ site is placed in a phase with Barnes. The Barnes site assemblage includes one piece of European copper as identified by Sanft using pXRF, charred human remains in middens, and a defensive location and partial palisade (Bradley 2005:35-37). Modeled as a Phase, both fall into a narrow date range at 1526-1540 and 15241540, respectively.

Temperance House and Atwell, considered the first "protohistoric" sites in the sequence, are estimated to date to $1545-1568$ and 15461569 respectively, followed by the Chase site with a modeled age estimate of 1574-1606. All are more or less in line with the chronology presented by Bradley and Tuck. Each of these sites were found to contain very small quantities of European goods. The Onondaga sequence ends with the Pompey Center site, which most likely dates to 1619-1639. An Interval between Chase and Pompey allows for sites in the local sequence, for which material could not be acquired, likely of $0-21(68.3 \%)$ or $0-42$ $(95.4 \%)$ years.

The most significant insights to emerge from the Onondaga sequence are the slightly later dates for the Howlett Hill and Schoff sites early in the sequence, and for Pompey Center at the very end. Incomplete understanding of site-level settlement patterns, small artifact assemblages, and lack of available samples with secure provenience for radiocarbon dating for most sites obscures deeper insight into this local sequence. We note, however, that evidence for conflict first appears here at the Bloody Hill site as early as 1460 , some $75-100$ years earlier than evidence for conflict on the north shore of Lake Ontario. 
A. TRADITIONAL REGIONAL CHRONOLOGY

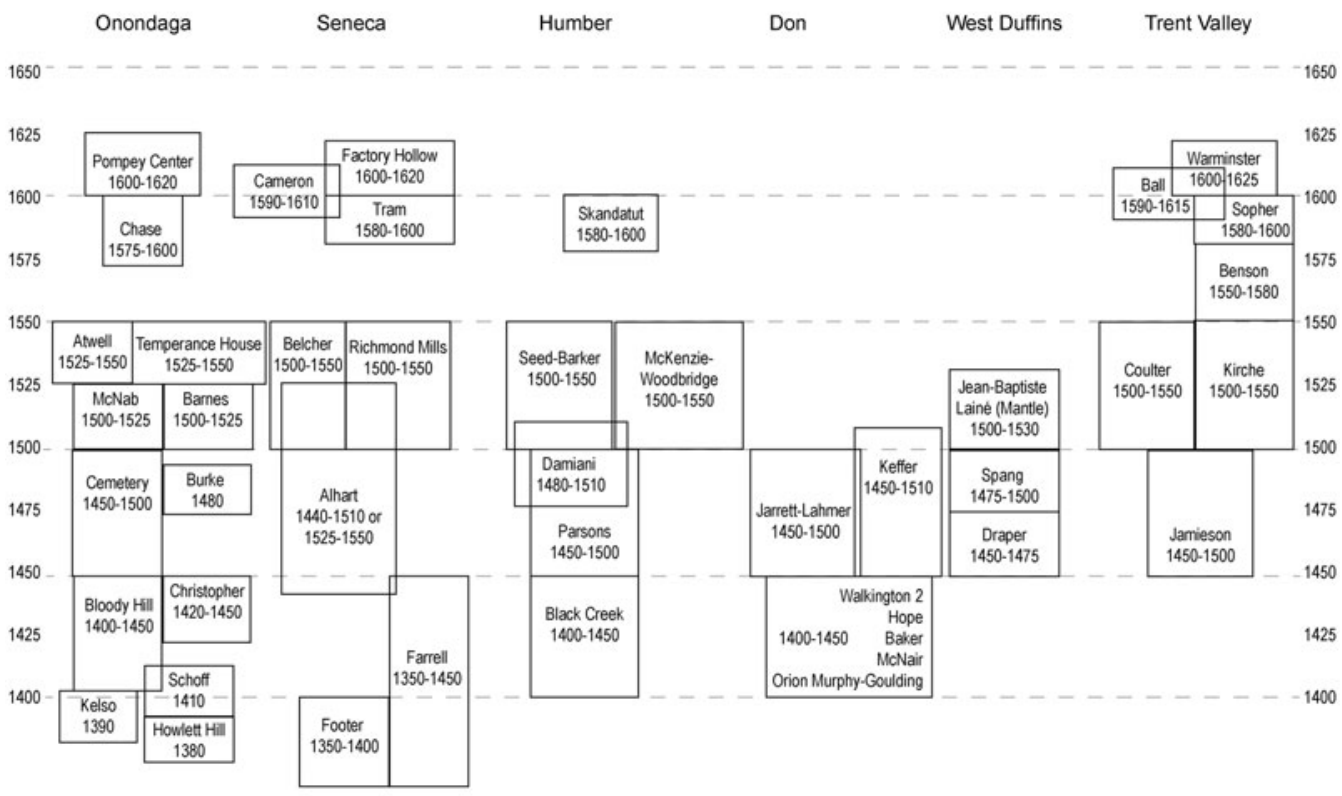

B. DATING IROQUOIA RADIOCARBON CHRONOLOGY

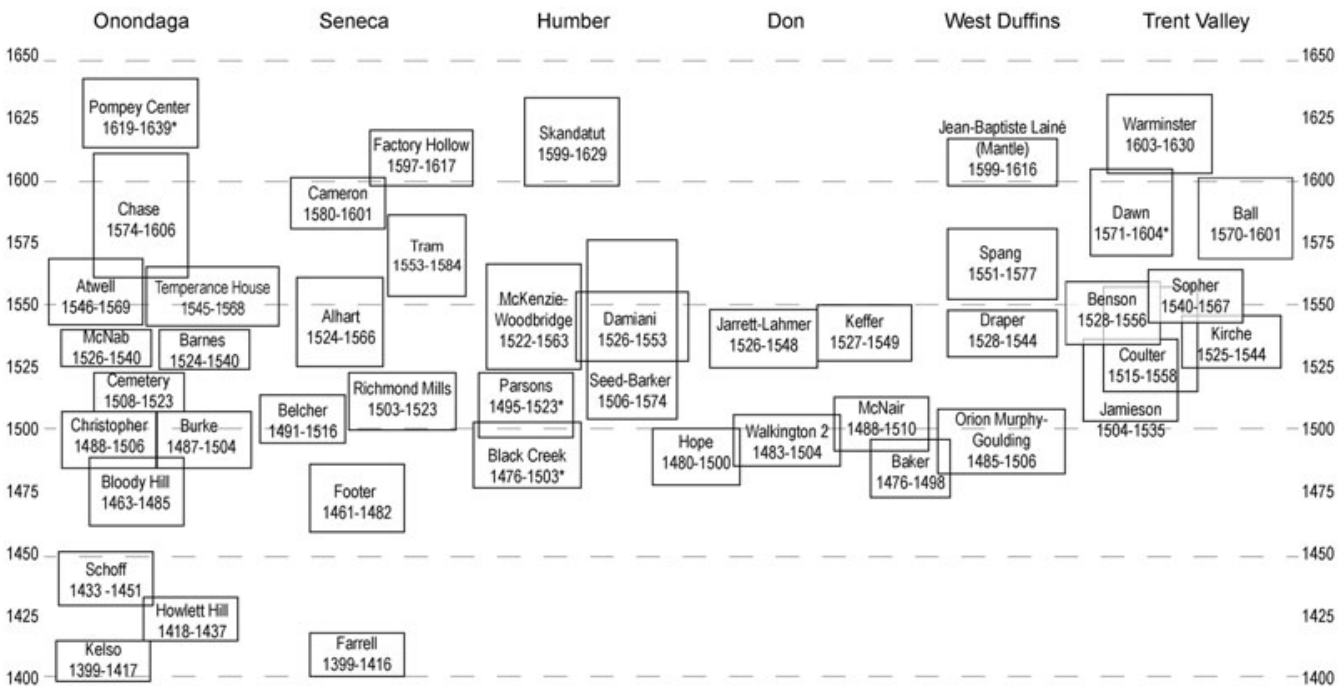

Figure 7. Previously accepted age estimates for Iroquoian village sites dated in this study compared to new, revised chronological associations for those same sites. Previous chronology modeled after Birch and Williamson (2013), Bradley (2005), Engelbrecht (2003), Hamell (1977), Niemczycki (1984), Sempowski and Saunders (2001), Ramsden (2016), and Tuck (1971).

\section{Discussion: A New History for Iroquoia}

These new date estimates for key sites and sequences represent a substantial replotting of the historical development of these two Northern
Iroquoian societies (Figure 7). We note and accept that the chronologies we have developed and presented are not independent of prior inferences due to the limitations of available data. We have used previous archaeological assessments of site 
sequences and order in several cases, and we have tentatively accepted these when the radiocarbon data successfully model consistent with these hypotheses. For example, in multiple site sequences, gaps between sites presumed to be sequential are present. These gaps may be real or an artifact of those samples selected or available for dating, and more dates representing the true occupational spans of sites are required in order to evaluate that question. This does not, of course, prove that these assumptions are correct, but it suggests that they are not substantially incorrect. However, placing these new radiocarbon data within models based on current best knowledge of the archaeology of the region, we find that we are nevertheless forced to rethink the basic time frames in which these sequences are placed, as well as the associated explanatory frameworks for processes of sociocultural development. The existing status quo cannot stand. Moving forward, we can then target the need for more independent chronological analysis and reform (since changing the prior assumptions will only make even more of a case for doing this). In the future, with many more ${ }^{14} \mathrm{C}$ dates and additional independent modeling-for example, as per techniques discussed elsewhere (Manning et al. 2020)_we can test even the general previous settlement sequence assumptions and further clarify the relevant time frames and site placements. Our findings indicate that this should be a research priority for the field.

\section{Implications for Coalescence and Conflict}

Arguably, the most significant shift in our understanding of the archaeological history of Iroquoia is the change in the timing of coalescence and conflict. Previously, the approximately 1450 1500 period in Ontario and the early to mid1500 s period in New York were understood to have represented the onset of settlement aggregation and endemic violence. Now, the earliest sites with clear signs of violent conflict (defensive siting, human remains bearing traumas) come from Onondaga (Bloody Hill) and Seneca (Belcher, Richmond Mills) territory sites and the Humber Valley (Black Creek) at the west end of Lake Ontario in the later 1400 s to early 1500 s. Small, unpalisaded sites to the northeast in the Don River sequence previously thought to date to roughly $1400-1450$ are now understood as dating to as much as a century later-this same later 1400 s to early 1500 s interval. Conflict does not come to the Don Valley until approximately 1525 , perhaps after the Middle Humber is abandoned. Date ranges for heavily palisaded sites in the Upper Humber similarly cluster around the early to mid-1500s. Previous work on the West Duffins Creek sequence (Manning et al. 2018) determined that the aggregated Draper community likewise formed in the mid-1500s-not around 1450 , as previously assumed. Together, the new data suggest that heightened conflict occurred first in western New York and around the west end of Lake Ontario in the late 1400s, and it then spread east by approximately 1525 . The palisading of sites in the Trent Valley occurred around and after the first decade of the 1500s. Another potentially earlier Trent Valley site with evidence for conflict, Quackenbush, could not be dated for this study. We acknowledge the need to consider how similar processes were playing out around the east end of Lake Ontario. Additional research has begun to provide new insights into how the defensive positions and eventual dispersal of St. Lawrence Iroquoian populations by around 1550 factor into the regional scene (Abel 2019; Abel et al. 2019).

All of the available data from the west end and north shore of Lake Ontario, however, are pointing to conflict within ancestral Haudenosaunee territory and between ancestral Haudenosaunee and ancestral Wendat communities-not internal conflict between ancestral Wendat communities, as has previously been understood. Although internal conflict between some Wendat communities is possible, the radiocarbon and settlement data strongly suggest that shifts in Wendat settlement patterns north along major drainages and the eventual consolidation of population in the Simcoe Uplands (historic Wendake) occurred with the intent of creating a buffer zone between the Wendat and the Haudenosaunee. The escalation of both internal and external conflict on the part of the Haudenosaunee coincides with the formation of village clusters associated with the formative Seneca and Onondaga nations.

In short, based on the data presented here, coalescence and conflict can now be understood as beginning in the Finger Lakes region and 
around the west end of Lake Ontario between populations ancestral to the Haudenosaunee and Wendat confederacies in the late 1400s and early 1500s. By the second decade of the 1500 s, communities around the west end of Lake Ontario were abandoned, creating a buffer zone between these emergent political entities. Conflict then spread to the rest of the region, such that by around 1525, all communities in both Ontario and New York had assumed a defensive posture in the context of heightened regional hostilities. The "traditional" hostilities between the Haudenosaunee and Wendat did not begin shortly before direct engagement with Europeans, as previously assumed (Trigger 1976). Instead, they had their roots as early as the late 1400 s, with widespread intersocietal conflict characterizing the region from about 1525 onward.

New understandings about the timing and directionality of conflict suggest that hostilities with the Haudenosaunee influenced the relocation of ancestral Wendat settlement northward in the sixteenth century and, ultimately, the formation of the Wendat Confederacy. The variability in the timelines between community sequences highlights that these relocations were not a discrete event but rather a protracted process that played out over more than two centuries. We acknowledge that a complex mix of internal and external factors were at work during processes of Wendat and Haudenosaunee politogenesis, and as such, no single "cause" led to the development of the allied Nations that came to identify themselves as confederacies. This revised timeline, however, provides a step toward an enhanced understanding of the different positionalities and dispositions of individual communities vis-à-vis coalescence, conflict, and initial processes of confederacy formation.

\section{Implications for Entry of European Goods}

Modeled dates both confirm and complicate current understandings of the timing and nature of Indigenous use of European goods. The first European-manufactured materials incorporated into Indigenous societies were fragments of copper and brass from kettles, along with iron from axes and nails, as early as the first half of the 1500s (at the sites of Richmond Mills, Barnes,
Seed-Barker, Mackenzie-Woodbridge, Coulter, Kirche, and Benson). These items are found in small numbers, and they are often worked into Indigenous cultural forms, illustrating how individuals indigenized European objects by repurposing them to fit their own desires and needs (e.g., Bradley and Childs 1991). Toward the end of the 1500s, assemblages on sites began to include European glass beads as well as European metals, first in small quantities (as seen at Tram and Chase), with numbers of both glass beads and metal objects increasing exponentially after approximately 1600 (as seen at Factory Hollow, Pompey Center, Skandatut, Warminster, and Ball).

It has also become clear that there was considerable variability among communities in terms of the initial appearance and use of European materials and, by proxy, engagement with European settlers. Although much of the trade goods data fit previously understood patterns, it is perhaps more interesting to discuss the sites that do not. The Jean-Baptiste Lainé (Mantle) site in the West Duffins Creek sequence was occupied at the turn of the seventeenth century, and it contained only three pieces of European metal (Birch and Williamson 2013; Manning et al. 2018), in contrast to sites now known to be contemporaneous - such as at Factory Hollow, Pompey Center, Skandatut, Warminster, and Ballfrom which hundreds of metal and glass objects have been recovered. Mid-sixteenth-century sites in the Don Valley (Jarret-Lahmer and Keffer) have no trade goods at all, contrasting with contemporaneous sites such as MackenzieWoodbridge and Seed-Barker, which are located only $10 \mathrm{~km}$ to the west. These latter sites were occupied at the same time as the neighboring Damiani site, which was fully excavated and yet produced no European-manufactured objects.

The variable distribution of European trade goods in space and time highlights the flawed nature of artifact frequency seriation. For the majority of the $1500 \mathrm{~s}$, European goods were not evenly distributed across the region and therefore can no longer be used as "horizon" markers. Results suggest that there was not synchronous access to and/or adoption of European goods throughout the 1500 s Northeast. This erases the idea that Indigenous peoples were 
passively accepting European goods, and it foregrounds Indigenous agency in trade-related decision-making processes. Although this complicates regional histories, it also arguably creates the space to ask questions that are more interesting. Perhaps the occupants of sites such as Jean-Baptiste Lainé, Jarrett-Lahmer, Keffer, and Damiani were intentionally choosing not to participate in the long-distance exchange networks operating at this time. Alternatively, perhaps they were being excluded from these networks for political or cultural reasons by virtue of who controlled those connections (as per Chapdelaine 2016). From the data presented, we can no longer safely assume that the timing of the introduction of European materials - and by proxy, the entry of Indigenous peoples into European politico-economic networks-was homogenous. We suggest that other factors relating to geography, political alignment, and/or Indigenous agency influenced the timing and tempo of those processes.

\section{Conclusions}

Past formulations of Iroquoian culture-history were based on imprecise-and in some cases, inaccurate-time frames that resulted in interpretations of processes of coalescence, conflict, and the introduction of European goods that flattened out variability in how these processes were actually enacted "on the ground." This is especially true in the context of traditional versus new understandings of early trade-good chronologies among ancestral Wendat peoples and assumptions about the timing and directionality of conflict. The effect of relying on such imprecise formulations is that history becomes presented as something that happens to people, as opposed to something that people actively produce as agents in their time.

Enhanced chronological resolution permits us to understand the past in a way that privileges relational histories (sensu Robb and Pauketat 2013). It forces us to acknowledge persons and communities as active decision makers, bound up in social and political networks, with specific social, geographic, and ecological contexts influencing their actions and reactions. These data make it clear that to say "the Wendat or
Haudenosaunee did $\mathrm{X}$ or $\mathrm{Y}$ " is erroneous. There were more complicated processes playing out within local communities that were not a microcosm of some greater cultural phase, but rather speak to distinct actions and responses to local contingencies and dispositions. More work remains to flesh out how this revised chronology will allow us to reposition communities in the social contexts that led to the development of tribal nations and confederacies in northeastern North America.

In redating the sites and sequences presented here, it was not our intent to simply reframe the culture-historical building blocks of northeastern archaeology_instead, we have sought to eliminate them. In this way, radiocarbon-based site-sequence chronologies allow us to appreciate the texture of local and regional histories. Rather than presenting a definitive revision, however, this work should be understood as a first step and call for further action (sensu Whittle 2018:248). It is our hope that the methods and results presented here will be met with additional efforts toward chronology building in eastern North America.

Supplemental Material. For supplemental material accompanying this article, visit https://doi.org/10.1017/aaq.2020.73.

Supplemental Figure 1. A. The OxCal $\operatorname{LnN}(\ln (20), \ln (2))$ prior probability distribution for site Phase duration. B. The Middle Humber model run without Interval constraints on the site Phase durations showing the (much longer) Interval estimates that result. C. The Interval estimates for the Middle Humber sites with the model using the $\operatorname{LnN}(\ln (20), \ln (2))$ prior for each site Phase duration-compared to those from B.

Supplemental Figure 2. A. Humber River Sequence plot and B. Date estimates with previous age-estimate indicated.

Supplemental Figure 3. A. Don Valley Sequence plot and B. Date estimates with previous age-estimate indicated by red line.

Supplemental Figure 4. A. Trent Valley Sequence plot and B. Date estimates with previous age-estimate indicated by red line.

Supplemental Fig 5. A. Seneca Sequence plot and B. Date estimates with previous age-estimate indicated by red line.

Supplemental Fig 6. A. Alhart site Phase plot and B. Date estimate.

Supplemental Figure 7. A. Onondaga Sequence plot and B. Date estimates with previous age-estimate indicated by dashed red line.

Supplemental Figure 8. Hope site modelled in isolation. A. with no site Phase duration constraint. B with the site Phase duration constraints in the Supplemental Table 4 model.

Supplemental Figure 9. Intervals calculated from the models in Supplemental Figure 8. A. The Hope site modelled in isolation with no site Phase duration constraints. B. The 
Hope site modelled in isolation but including the site Phase constraints in Supplemental Table 4. C. The results of the Difference query applied to the period between the start and end Boundaries for the overall Hope site with a $\mathrm{N}(20,10)$ prior.

Supplemental Figure 10. Re-run of the Seneca model (Supplemental Table 6) without the assumed site relationships used there-i.e. all sites treated as independent.

Supplemental Figure 11. The effect of incorporating prior expert knowledge for the Seneca model. A. Site Date estimates for the Seneca model from Supplemental Figure 10 with no prior expert knowledge. B. Site Date estimates for the Seneca model if we do incorporate prior expert knowledge about site relationships.

Supplemental Figure 12. Comparison of the 34 instances where the identical sample was split between the University of Georgia (UGAMS) and the Groningen (GrM) radiocarbon laboratories.

Supplemental Table 1. All 184 Radiocarbon Samples and Conventional Radiocarbon Ages (CRA) used in this study.

Supplemental Table 2. Descriptive information for all sites dated in this study.

Supplemental Table 3. OxCal runfiles for Middle and then Upper Humber Valley sequences.

Supplemental Table 4. OxCal runfile for Don Valley sequence.

Supplemental Table 5. OxCal runfile for Trent Valley sequence.

Supplemental Table 6. OxCal runfile for Seneca sequence.

Supplemental Table 7. OxCal runfile for the Alhart site.

Supplemental Table 8. OxCal runfile for the Onondaga sequence.

Supplemental Table 9. Order analysis from the Don Valley model for the precoalescent site Phase.

Supplemental Table 10. Comparison of the dating ranges for the Sopher, Ball and Warminster sites from the Trent model depending on whether or not an approximate contiguous order of Ball then Warminster is used.

Supplemental Table 11. Comparison of Date estimate results for the Humber model using no prior, versus several different priors.

Supplemental Table 12. Comparison of date ranges for the Hope site considering three different prior assumptions for the overall duration of the site versus no prior assumptions for any of the site Phase durations in the Don Valley model.

Supplemental Table 13. The start and end Boundaries calculated for each of the sites from the modelled site sequences.

Supplemental Table 14. Comparison of the Date estimates for the Benson, Sopher, Ball and Warminster sites from the models in this paper versus those from the Manning et al. (2019) paper re-run with IntCal20.

Supplemental Table 15. The results from the model for the Onondaga Sequence in Table 2 and Supplemental Tables 13 run, as in Supplemental Table, and applying the OxCal outlier models, compared to running the same model with the 4 outliers included but with the outlier models applied.

Supplemental Table 16. The results from the model for the Onondaga Sequence in Table 2 and Supplemental Tables 13 and 15 run, as in Supplemental Table 8, applying the OxCal outlier models, are compared to running an example of the same model minus the same four outliers but with no outlier models then applied.

Acknowledgments. We thank Jim Bradley and Greg Sohrweide for assistance with acquiring Onondaga samples; George Hamell for assistance with acquiring Seneca-region samples; Peter Ramsden for providing samples from the Trent Valley; Ron Williamson and the staff of Archaeological Services Inc. for providing access to samples from southern Ontario; Neil Ferris for access to samples at Sustainable Archaeology: Western and the Museum of Ontario Archaeology; Chris Watts for access to samples at the University of Waterloo; Scott Martin for access to samples held at Sustainable Archaeology McMaster; Trevor Orchard for access to samples held at University of Toronto Mississauga; Kathryn David and Ted Banning for samples at University of Toronto; Douglas Armstrong for access to samples curated at Syracuse University; John Hart, Jonathan Lothrop, Andrea Lain, Ralph Rataul, and Susan Winchell-Sweeney for access to samples and data from the New York State Museum; Kathryn Murano Santos for access to Rochester Museum \& Science Center samples; and Louis Lesage of the Huron-Wendat Nation for his collaboration and comments on a draft of this article. Funding for this project was provided by the National Science Foundation (Award \#1727802).

Data Availability Statement. All data used in the analyses for this article are included in the Supplemental Materials and available via the Digital Archaeological Record (tDAR) and the Canadian Archaeological Radiocarbon Database (CARD).

\section{References Cited}

Abel, Timothy J.

2019 New Radiocarbon Dates for the Iroquoian Occupation of Northern New York. Archaeology of Eastern North America 47:23-38.

Abel, Timothy J., Jessica L. Vavrasek, and John P. Hart

2019 Radiocarbon Dating the Iroquoian Occupation of Northern New York. American Antiquity 84:748-61.

Anselmi, Lisa

2004 New Materials, Old Ideas: Native Use of European-Introduced Metals in the Northeast. PhD dissertation, Department of Anthropology, University of Toronto, Toronto.

ASI (Archaeological Services Inc.)

2012 Stage 3 Archaeological Resource Assessment beyond the North Limits of the Skandatut Site (AlGv-193), Lot 24, Concession 7, Geographic Township of Vaughan, City of Vaughan, Ontario. Report on file Ontario Ministry of Recreation, Tourism, and Sport, Toronto.

2015 The Archaeology of the Damiani Site (AlGv-231): A Report on the Stage 4 Mitigative Excavation of the Damiani Site (AlGv-231), Part of Lot 25, Concession 7, Pine Heights Estates, Blocks 40 and 47, City of Vaughan, Municipality of York, Ontario. Report on file with Ontario Ministry of Tourism, Culture, and Sport, Toronto.

Bayliss, Alex

2009 Rolling Out Revolution: Using Radiocarbon Dating in Archaeology. Radiocarbon 51:123-147. 
2015 Quality in Bayesian Chronological Models in Archaeology. World Archaeology 47:677-700.

Bayliss, Alex, and Christopher Bronk Ramsey

2004 Pragmatic Bayesians: A Decade of Integrating Radiocarbon Dates into Chronological Models. In Tools for Constructing Chronologies: Tools for Crossing Disciplinary Boundaries, edited by Caitlyn E. Buck and Andrew R. Millard, pp. 25-41. Springer, London.

Biggar, Henry Percival (editor)

1929-1936 The Works of Samuel de Champlain. 6 vols. Champlain Society, Toronto.

Birch, Jennifer

2010 Coalescence and Conflict in Iroquoian Ontario. Archaeological Review from Cambridge 25(1):27-46.

2012 Coalescent Communities: Settlement Aggregation and Social Integration in Iroquoian Ontario. American Antiquity 77:646-670.

2015 Current Research on the Historical Development of Northern Iroquoian Societies. Journal of Archaeological Research 23:263-323.

Birch, Jennifer, and John P. Hart

2018 Social Networks and Northern Iroquoian Confederacy Dynamics. American Antiquity 83:13-33.

Birch, Jennifer, and Ronald F. Williamson

2013 The Mantle Site: An Archaeological History of an Ancestral Wendat Community. AltaMira, Lanham, Maryland.

Bradley, James W.

1980 Dutch Bale Seals from 17th Century Onondaga Iroquois Sites in New York State. Post-Medieval Archaeology 14:197-200.

2005 Evolution of the Onondaga Iroquois: Accommodating Change 1500-1655. Syracuse University Press, Syracuse, New York.

Bradley, James W.

2007 Before Albany: An Archaeology of Native-Dutch Relations in the Capital Region 1600-1664. New York State Museum Bulletin 509. New York State Education Department, Albany.

Bradley, James W., and Terry S. Childs

1991 Basque Earrings and Panther's Tails: The Form of Cross-Cultural Contact in Sixteenth-Century Iroquoia In Metals in Society: Theory Beyond Analysis, edited by Robert M. Ehrenreich, pp. 7-17. MASCA Research Papers in Science and Archaeology 8(2). University Museum of Archaeology and Anthropology, University of Pennsylvania, Philadelphia.

Bronk Ramsey, Christopher

2009a Bayesian Analysis of Radiocarbon Dates. Radiocarbon 51:337-360.

2009b Dealing with Outliers and Offsets in Radiocarbon Dating. Radiocarbon 51:1023-1045.

Bronk Ramsey, Christopher, Michael W. Dee, Joanne M. Rowland, Thomas F. G. Higham, Stephen A. Harris, Fiona Brock, Anita Quiles, Eva M. Wild, Ezra S. Marcus, and Andrew J. Shortland

2010 Radiocarbon-Based Chronology for Dynastic Egypt. Science 328:1554-1557.

Chapdelaine, Claude

2016 Saint Lawrence Iroquoians as Middlemen or Observers: Review of Evidence in the Middle and Upper Saint Lawrence Valley. In Contact in the 16th Century: Networks among Fishers, Foragers, and Farmers, edited by Brad Loewen, and Claude Chapdelaine, pp. 149170. Mercury Series, Archaeology Paper 176. Canadian
Museum of History, Gatineau, Quebec; University of Ottawa Press, Canada.

Damkjar, Eric

2009 The Coulter Site and Late Iroquoian Coalescence in the Upper Trent Valley. 2nd ed. Occasional Papers in Northeastern Archaeology No. 2. Copetown Press, St. John's, Newfoundland, Canada.

Dee, Michael W., and Christopher Bronk Ramsey

2014 High-Precision Bayesian Modeling of Samples Susceptible to Inbuilt Age. Radiocarbon 56:83-94.

Dee, Michael W., David Wengrow, Andrew Shortland, Alice Stevenson, Fiona Brock, Linus Girdland Flink, and Christopher Bronk Ramsey

2013 An Absolute Chronology for Early Egypt Using Radiocarbon Dating and Bayesian Statistical Modelling. Proceedings of the Royal Society A: Mathematical, Physical, and Engineering Sciences 469 (2159):20130395. DOI:10.1098/rspa.2013.0395.

Dupras, Tosha L., and David G. Pratte

1998 Craniometric Study of the Parsons Crania from Midden 4/Feature 245. Ontario Archaeology 65/ 66:140-145.

Ellis, Chris J., and Neal Ferris (editors)

1990 The Archaeology of Southern Ontario to A.D. 1650. Occasional Publication of the London Chapter, OAS Number 5. London Chapter, Ontario Archaeological Society, London, Ontario, Canada.

Emerson, John Norman

1954 The Archaeology of the Ontario Iroquois. $\mathrm{PhD}$ dissertation, Department of Anthropology, University of Chicago, Chicago.

Engelbrecht, William E.

1971 A Stylistic Analysis of New York Iroquois Pottery. PhD dissertation, Department of Anthropology, University of Michigan, Ann Arbor.

Engelbrecht, William E.

2001 [1981] Comments on Ceramics from the Footer and Farrell Farm Sites. Iroquoian 26:21-25.

Engelbrecht, William E.

2003 Iroquoia: The Development of a Native World. Syracuse University Press, Syracuse, New York.

Fenton, William N.

1998 The Great Law and the Longhouse: A Political History of the Iroquois Confederacy. University of Oklahoma Press, Norman.

Ferris, Neal, and Michael W. Spence

1995 The Woodland Traditions in Southern Ontario. Revista de Arqueología Americana 9:83-138.

Finlayson, William D.

1985 The 1975 and 1978 Rescue Excavations at the Draper Site: Introduction and Settlement Patterns. Archaeological Survey of Canada Mercury Series Paper 130. National Museums of Canada, Ottawa.

Finlayson, William D., David G. Smith, Michael W. Spence, and Peter A. Timmins

1987 The 1985 Salvage Excavations at the Keffer Site: A License Report. Report on file with the Ontario Ministry of Culture, Toronto.

Fitzgerald, William R.

1990 Chronology to Cultural Process: Lower Great Lakes Archaeology, 1500-1650. PhD dissertation, Department of Anthropology, McGill University, Montreal.

1995 A Late Sixteenth-Century European Trade Assemblage from North-Eastern North America. In Trade and Discovery: The Scientific Study of Artefacts from Post-Medieval Europe and Beyond, edited by Duncan 
R. Hook and David R. M. Gaimster, pp. 29-44. Occasional Paper No. 109. British Museum Press, London.

Fitzgerald, William R., Laurier Turgeon, Ruth Holmes Whitehead, and James W. Bradley

1993 Late Sixteenth-Century Basque Banded Copper Kettles. Historical Archaeology 27(1):44-57.

Fox, William A., Ronald G. V. Hancock, and Laurence A. Pavlish

1995 Where East Met West: The New Copper Culture. Wisconsin Archaeologist 76(3/4):269-293.

Gaudreau, Marianne, and Louis Lesage

2016 Understanding Ethnicity and Cultural Affiliation: Huron-Wendat and Anthropological Perspectives. Ontario Archaeology 96:6-16.

Hamell, George M.

1977 Report on the Alhart Site Radiocarbon Dates. Report on file, Rochester Museum and Science Center, New York.

Hart, John P.

2011 The Death of Owasco - Redux. In Current Research in New York Archaeology: AD 700-1300, edited by Christina B. Rieth and John P. Hart, pp. 95-107. New York State Museum Record 2. New York State Education Department, Albany.

Hart, John P., and Hetty Jo Brumbach

2003 The Death of Owasco. American Antiquity 68:737752.

Hart, John P., Susan Winchell-Sweeney, and Jennifer Birch 2019 An Analysis of Network Brokerage and Geographic Location in Fifteenth-Century AD Northern Iroquoia. PLoS ONE 14(1):e0209689. DOI:10.1371/journal. pone.0209689.

Hawkins, Alicia L., Joseph A. Petrus, Lisa Marie Anselmi, and Gary Crawford

2016 Laser Ablation-Inductively Coupled Plasma-Mass Spectrometry Analysis of Copper-Based Artifacts from Southern Ontario and the Chronology of the Indirect Contact Period. Journal of Archaeological Science: Reports 6:332-341.

Higham, Charles, and Thomas Higham

2009 A New Chronological Framework for Prehistoric Southeast Asia, Based on a Bayesian Model from Ban Non Wat. Antiquity 83:125-144.

Jones, Eric E., and James W. Wood

2012 Using Event-History Analysis to Examine the Causes of Semi-Sedentism among Shifting Cultivators: A Case Study of the Haudenosaunee, AD 1500-1700. Journal of Archaeological Science 39:2593-2603.

Jordan, Kurt A.

2009 Colonies, Colonialism, and Cultural Entanglement: The Archaeology of Postcolumbian Intercultural Relations. In International Handbook of Historical Archaeology, edited by Teresita Majewski and David R. Gaimster, pp. 31-49. Springer, New York.

2013 Incorporation and Colonization: Postcolumbian Iroquois Satellite Communities and Processes of Indigenous Autonomy. American Anthropologist 115:29-43.

Kenyon, Ian, and William Fitzgerald

1986 Dutch Glass Beads in the Northeast: An Ontario Perspective. Man in the Northeast 32:1-34.

Kenyon, Ian T., and Thomas A. Kenyon

1983 Comments on 17th Century Glass Trade Beads from Ontario. In Proceedings of the 1982 Glass Trade Bead Conference, edited by Charles F. Hayes III, pp. 59-74. Research Records No. 16. Rochester Museum and Science Center, New York.
Kosiba, Steve

2019 New Digs: Networks, Assemblages, and the Dissolution of Binary Categories in Anthropological Archaeology. American Anthropologist 121:447-463.

Loewen, Brad

2016 Sixteenth-Century Beads: New Data, New Directions. In Contact in the 16th Century: Networks among Fishers, Foragers, and Farmers, edited by Brad Loewen, and Claude Chapdelaine, pp. 149-70. Mercury Series Archaeology Paper 176. Canadian Museum of History, Gatineau, Quebec; University of Ottawa Press, Ottawa, Canada.

Loewen, Brad, and Claude Chapdelaine (editors)

2016 Contact in the 16th Century: Networks among Fishers, Foragers, and Farmers. Mercury Series Archaeology Paper 176. Canadian Museum of History, Gatineau, Quebec; and University of Ottawa Press, Ottawa, Canada

MacNeish, Robert S.

1952 Iroquois Pottery Types: A Technique for the Study of Iroquois Prehistory. National Museum of Canada Bulletin No. 124, Anthropological Series No. 31. Department of Resources and Development, Government of Canada.

Manning, Sturt W., Jennifer Birch, Megan Anne Conger, Michael W. Dee, Carol Griggs, and Carla S. Hadden

2019 Contact-Era Chronology-Building in Iroquoia: Age Estimates for Arendarhonon Sites and Implications for Identifying Champlain's Cahiagué. American Antiquity 84:684-707.

Manning, Sturt W., Jennifer Birch, Megan Anne Conger, Michael W. Dee, Carol Griggs, Carla S. Hadden, Alan G. Hogg, Christopher Bronk Ramsey, Samantha Sanft, Peter Steier, and Eva M. Wild

2018 Radiocarbon Re-dating of Contact Era Iroquoian History in Northeastern North America. Science Advances 4(12):eaav0280. DOI:10.1126/sciadv. aav0280

Manning, Sturt W., Jennifer Birch, Megan Anne Conger, and Samantha Sanft

2020 Resolving Time among Non-Stratified ShortDuration Contexts on a Radiocarbon Plateau: Possibilities and Challenges from the AD 1480-1630 Example and Northeastern North America. Radiocarbon, in press. DOI:10.1017/RDC.2020.51.

Manning, Sturt, and John P. Hart

2019 Radiocarbon, Bayesian Chronological Modeling and Early European Metal Circulation in the SixteenthCentury AD Mohawk River Valley, USA. PLOS One 4 (12):e0226334. DOI:10.1371/journal.pone.0226334.

Manning, Sturt W., Christopher Bronk Ramsey, Walter Kutschera, Thomas Higham, Bernd Kromer, Peter Steier, and Eva M. Wild

2006 Chronology for the Aegean Late Bronze Age 17001400 B.C. Science 312:565-569.

Nasmith, Carol

2008 The Kirche Site: A 16th Century Huron Village in the Upper Trent Valley. Occasional Papers in Northeast Archaeology No. 1. Copetown Press, St. John's, Newfoundland, Canada.

Natural Earth

2019 Vector and Raster Map Data. Electronic document, https://www.naturalearthdata.com/, accessed June 28, 2019.

Needham, Stuart, Christopher Bronk Ramsey, David Coombs, Caroline Cartwright, and Paul Pettitt 
1998 An Independent Chronology for British Bronze Age Metalwork: The Results of the Oxford Radiocarbon Accelerator Programme. Archaeological Journal 154:55-107.

Niemczycki, Mary Ann Palmer

1984 The Origin and Development of the Seneca and Cayuga Tribes of New York State. Research Records No. 17. Research Division, Rochester Museum and Science Center, New York.

Parker, Arthur C.

1918 A Prehistoric Iroquoian Site on the Reed Farm, Richmond Mills, Ontario County, N.Y. Researches and Transactions of the New York State Archaeological Association, Morgan Chapter, Vol 1. C. F. Milliken, Canandaigua, New York.

Pihl, Robert H., Steven G. Monckton, David A. Robertson, and Ronald F. Williamson

2008 Settlement and Subsistence Change at the Turn of the First Millennium: The View from the Holmedale Site, Brantford, Ontario. Current Northeast Paleoethnobotany II, edited by John P. Hart, pp. 151-172. University of the State of New York, New York Education Department, Albany.

Ramsden, Peter G.

1977 A Refinement of Some Aspects of Huron Ceramic Analysis. Archaeological Survey of Canada Mercury Series Paper 63. National Museums of Canada, Ottawa.

1978 An Hypothesis Concerning the Effects of Early European Trade among Some Ontario Iroquois. Canadian Journal of Archaeology 2:101-106.

1990 The Hurons: Archaeology and Culture History. In The Archaeology of Southern Ontario to A.D. 1650, edited by Chris J. Ellis and Neal Ferris, pp. 361-384. Occasional Publication of the London Chapter, OAS Number 5. London Chapter, Ontario Archaeological Society, London, Ontario.

2009 Politics in a Huron Village. In Painting the Past with a Broad Brush: Papers in Honour of James Valliere Wright, edited by David Keenlyside and JeanLuc Pilon, pp. 299-318. Mercury Series Archaeology Paper 170. Canadian Museum of Civilization, Gatineau, Quebec.

2014 Review of the Mantle Site. An Archaeological History of an Ancestral Wendat Community. North Atlantic Archaeology 3:134-137.

2016 Becoming Wendat: Negotiating a New Identity around Balsam Lake in the Late Sixteenth Century. Ontario Archaeology 96:121-133.

Reimer, Paula J., William E. N. Austin, Edouard Bard, Alex Bayliss, Paul G. Blackwell, Christopher Bronk Ramsey, Martin Butzin, Hai Cheng, R. Lawrence Edwards, Michael Friedrich, Pieter M. Grootes, Thomas P. Guilderson, Irka Hajdas, Timothy J. Heaton, Alan G. Hogg, Kon$\operatorname{rad}$ A. Hughen, Bernd Kromer, Sturt W. Manning, Raimund Muscheler, Jonathan G. Palmer, Charlotte Pearson, Hans van der Plicht, Ron W. Reimer, David A. Richards, E. Marian Scott, John R. Southon, Christian S. M. Turney, Lukas Wacker, Florian Adolphi, Ulf Büntgen, Manuela Capano, Simon M. Fahrni, Alexandra Fogtmann-Schulz, Ronny Friedrich, Peter Köhler, Sabrina Kudsk, Fusa Miyake, Jesper Olsen, Frederick Reinig, Minoru Sakamoto, Adam Sookdeo, and Sahra Talamo

2020 The IntCal20 Northern Hemisphere Radiocarbon Age Calibration Curve (0-55 kcal BP). Radiocarbon, in press. DOI:10.1017/RDC.2020.41.
Reimer, Paula J., Edouard Bard, Alex Bayliss, J. Warren Beck, Paul G. Blackwell, Christopher Bronk Ramsey, Caitlin E. Buck, Hai Cheng, R. Lawrence Edwards, Michael Friedrich, Pieter M. Grootes, Thomas P. Guilderson, Haflidi Haflidason, Irka Hajdas, Christine Hatté, Timothy J. Heaton, Dirk L. Hoffman, Alan G. Hogg, Konrad A. Hughen, K. Felix Kaiser, Bernd Kromer, Sturt W. Manning, Mu Niu, Ron W. Reimer, David A. Richards, E. Marian Scott, John R. Southon, Richard A. Staff, Christian S. M. Turney, and Johannes van der Plicht

2013 IntCal13 and Marine13 Radiocarbon Age Calibration Curves 0-50,000 Years cal BP. Radiocarbon 55:1869-1887.

Robb, John, and Timothy R. Pauketat

2013 From Moments to Millennia: Theorizing Scale and Change in Human History. In Big Histories, Human Lives: Tackling Problems of Scale in Archaeology, edited by John Robb and Timothy R. Pauketat, pp. 3-34. School for Advanced Research Press, Santa Fe, New Mexico.

Rossen, Jack

2015 Introduction. In Corey Village and the Cayuga World: Implications from Archaeology and Beyond, edited by Jack Rossen, pp. 1-34. Syracuse University Press, Syracuse, New York.

Rumrill, Donald A.

1991 The Mohawk Glass Trade Bead Chronology: ca. 1560-1785. Beads: Journal of the Society for Bead Research 3:5-45.

Sempowski, Martha L., and Lorraine P. Saunders

2001 Dutch Hollow and Factory Hollow: The Advent of Dutch Trade among the Seneca. Charles F. Wray Series in Seneca Archaeology Volume III, Research Records No. 24. Collections Department of the Rochester Museum and Science Center, Rochester, New York.

Snow, Dean R.

1994 The Iroquois. Blackwell Publishers, Cambridge.

1995 Mohawk Valley Archaeology: The Sites. Matson Museum of Anthropology Occasional Papers in Anthropology No. 23. Pennsylvania State University, University Park.

Thwaites, Reuben Gold

1896-1901 The Jesuit Relations and Allied Documents. 73 vols. Burrows Brothers, Cleveland, Ohio.

Trigger, Bruce G.

1976 The Children of Aataentsic: A History of the Huron People to 1660. McGill-Queen's University Press, Montreal and Kingston.

Tuck, James A.

1971 Onondaga Iroquois Prehistory: A Study in Settlement Archaeology. Syracuse University Press, Syracuse, New York.

Turgeon, Laurier

2001 French Beads in France and Northeastern North America during the Sixteenth Century. Historical Archaeology 35(4):58-82.

United States Geological Survey

2017 The National Map, 3DEP Products and Services: The National Map, 3D Elevation Program. Electronic document, https://nationalmap.gov/3DEP/3dep_prodserv. html, accessed November 13, 2019.

Walder, Heather

2018 Small Beads, Big Picture: Assessing Chronology, Exchange, and Population Movement through 
Compositional Analyses of Blue Glass Beads from the Upper Great Lakes. Historical Archaeology 52:301331.

Warrick, Gary A.

1988 Estimating Ontario Iroquoian Village Duration. Man in the Northeast 36:21-60.

2000 The Precontact Iroquoian Occupation of Southern Ontario. Journal of World Prehistory 14:415-466.

2008 A Population History of the Huron-Petun, AD 500 1650. Cambridge University Press, Cambridge.

Whittle, Alasdair

2018 The Times of Their Lives: Hunting History in the Archaeology of Neolithic Europe. Oxbow Books, Oxford.

Whittle, Alasdair, Alex Bayliss, and Frances Healy

2011 Gathering Time: Dating the Early Neolithic Enclosures of Southern Britain and Ireland. Oxbow Books, Havertown, Pennsylvania.

Williamson, Ronald F.

1999 Toward a Grounded Archaeology. In Taming the Taxonomy: Toward a New Understanding of Great Lakes Archaeology, edited by Ronald F. Williamson and Christopher M. Watts, pp. 3-8. Eastendbooks, Toronto.

2007 "Ontinontsiskiaj Ondaon" ("The House of Cut-Off Heads"): The History and Archaeology of Northern Iroquoian Trophy Taking. In The Taking and Displaying of Human Body Parts as Trophies by Amerindians, edited by Richard J. Chacon, and David H. Dye, pp. 190-221. Springer Books, New York.

2014 An Archaeological History of the Wendat to A.D. 1651: An Overview. Ontario Archaeology 94:3-65.
Williamson, Ronald F., and David A. Robertson 1995 The Archaeology of the Parsons Site: A Fifty Year Perspective. Report submitted to the Ontario Ministry of Citizenship, Culture, and Recreation, Toronto.

Wray, Charles F., and Henry Schoff

1953 A Preliminary Report on the Seneca Sequence in Western New York, 1550-1687. Pennsylvania Archaeologist 23(2):53-63.

Wray, Charles F., Martha L. Sempowski, and Lorraine P. Saunders

1991 Tram and Cameron: Two Early Contact Era Seneca Sites. Charles F. Wray Series in Seneca Archaeology Vol. 2. Rochester Museum and Science Center, Rochester, New York.

Wray, Charles F., Martha L. Sempowski, Lorraine P. Saunders, and Gian Carlo Cervone

1987 The Adams and Culbertson Sites. Charles F. Wray Series in Seneca Archaeology Vol. 1. Rochester Museum and Science Center, Rochester, New York.

Wright, James V.

1966 The Ontario Iroquois Tradition. National Museum of Canada Bulletin 210. National Museum of Man, Ottawa.

Wrong, George M. (editor)

1939 [1632] The Long Journey to the Country of the Hurons by Gabriel Sagard. Champlain Society, Toronto.

Submitted March 12, 2020; Revised June 29, 2020; Accepted June 29, 2020 